\title{
Leukemia and Lymphoma of Natural Killer Cells
}

\author{
Ritsuro Suzuki
}

Malignant hematolymphoid disorders arising from NK cells have become widely recognized over the past decade. The two forms of NK-cell malignancy, aggressive NK-cell leukemia (ANKL) and extranodal NK-cell lymphoma of nasal type (ENKL) are both characterized by the proliferation of tumor cells with an NK-cell like immunophenotype. ANKL usually presents with bone marrow tumor cells accompanied by circulating leukemic cells, and hepatosplenomegalay is a common clinical feature. ENKL most frequently affects the nasal or paranasal regions, with cutaneous involvement also being common. Approximately 70 percent of ENKL present with localized tumor cells, and follow an indolent clinical course, but, in advanced cases, tumors rapidly expand and are frequently fatal. Tumor cells from both ANKL and ENKL are surface CD3 ${ }^{-}$and CD56 ${ }^{+}$but differ in their expression of CD16. Epstein-Barr virus (EBV) is found in most cases of NK-cell leukemia/lymphoma, suggesting an oncogenic role, but patients may have biclonal or polyclonal populations of malignant cells based on differential EBV genome incorporation. NK-cell neoplasms are frequently resistant to chemotherapy due to p-glycoprotein expression and associated multidrug resistance. The prognoses of both localized and advanced stages of NK-cell malignancies are worse than most other lymphoid malignancies, but studies are currently underway to assess the safety and efficacy of novel chemoradiotherapy regimens for the treatment of these neoplasms.

\section{INTRODUCTION}

The classification of lymphoid neoplasms has changed much in recent years. In the Working Formulation ${ }^{1}$, lymphocyte lineage was not a factor in neoplasm classification, but the Revised-European-American Classification for Lymphoid Neoplasms (REAL Classification) once again adopted these standards, originally in place in the Kiel Classification ${ }^{2,3}$. However, neoplasms arising from NK-cells were not correctly defined in the REAL Classification, and inclusion of NK-cell neoplasms did not occur until the new World Health Organization (WHO) Classification ${ }^{4}$. In addition to aggressive NK-cell leukemia (ANKL) and extranodal NK-cell lymphoma, nasal type (ENKL), which are listed in the WHO Classification, there are several provisional categories of NK-cell neoplasms (Table 1). In this review, I describe the history of NK-cell neoplasms and the future prospects for disease management and treatment for these malignancies with extremely poor prognoses.

\section{Definition of NK-cells}

NK-cells were first recognized as a functional subset of lymphocytes mediating major histocompatibility complex-nonrestricted cytotoxicity ${ }^{5}$. NK-cells are morphologi-

Received: Aug 22, 2005

Accepted: Aug 23, 2005

Division of Molecular Medicine, Aichi Cancer Center, Nagoya, Japan.

Address correspondence and reprint request to Ritsuro Suzuki, Division of Molecular,

Aichi Cancer Center, 1-1 Kanokoden, chikusa-ku, Nagoya 464-8681, Japan cally large granular lymphocytes (LGLs), with germline Tcell receptor (TCR) and immunoglobulin gene configurations. Additionally, they are surface CD3 (sCD3)-negative and CD56-positive ${ }^{6}$. Based on these results, NK-cells are considered as the third lineage of lymphocyte distinct from T- and B-cells. Currently, two types of NK-cells are now proposed, cytotoxic NK-cells and immunoregulatory NK-cells ${ }^{7}$. It remains unclear whether these are distinct NK-cell subtypes or if differential cytokine exposure causes phenotypic interchangeability. During development, NK-cells arise from T/ NK bi-potential common progenitors ${ }^{8,9}$. Therefore, NK-cells are functionally and phenotypically very similar to T-cells, particularly cytotoxic T-cells; this renders the differential diagnosis of NK-cell neoplasms difficult.

Table 1. List of NK-cell neoplasms

\begin{tabular}{ll}
\hline \multicolumn{1}{c}{ Disease } & Abbreviation \\
\hline $\begin{array}{l}\text { 1. Precursor NK-cell neoplasms } \\
\text { (1) Myeloid/NK cell precursor acute leukemia }\end{array}$ & MNKL \\
(2) Blastic NK cell lymphoma & BNKL \\
2. Mature NK-cell neoplasms & \\
(1) Aggressive NK-cell leukemia & ANKL \\
(2) Extranodal NK-cell lymphoma, nasal type & ENKL \\
(3) Chronic NK-cell lymphocytosis* & CNKL \\
\hline
\end{tabular}

* Uncertain malignant potential. 


\section{R. Suzuki}

\section{Recognition of NK-cell leukemia and lymphoma}

Leukemia of NK-cells was first described by Fernandez et al. and Koizumi et al. in 1986 as "aggressive NK-cell leukemia (ANKL)" (Fig. 1) 10,11. Both groups demonstrated NK-activity and IL-2 responsiveness in the leukemic cells and concluded the neoplasms were of NK-cell origin. Imamura et al. also identified leukemia of NK-cell origin, but their findings were not published for several years ${ }^{12}$. Based on cellular morphology, these malignancies were considered a type of LGL leukemia ${ }^{13}$, but we now know that this classification encompasses a very heterogeneous collection of diseases. Alternative names for ANKL were aggressive LGL leukemia, non-T LGL leukemia, and NK-LGL leukemia, and in the REAL Classification this disease entity was given the new category LGL leukemia, NK-cell type (Fig. 1) ${ }^{3}$. However, this categorization emphasized the morphological features of the leukemic cells, rather than cell origin. Chronic T-LGL leukemia, also classified as an LGL leukemia, exhibits the same cellular morphology as ANKL, but dramatically differs in cell origin, phenotype, genotype, function and clinical course, and these differences are summarized in Table $2^{13,14}$. These differences led to the recognition of ANKL as a separate entity from T-LGL leukemia in the WHO Classification.

Lymphoma of NK-cells was originally incorrectly identified as T-cell lymphoma of nasal origin because of the phenotypic similarity of T-cells and NK-cells ${ }^{15}$. Lethal midline granuloma was a disease of undetermined neoplastic signifi- cance occurring in the mid facial area, and biopsied specimens from these lesions exhibited marked necrosis with inflammatory changes. Ishii et al. first recognized the presence of tumor cells expressing CD3 in this lesion and termed this disease "nasal T-cell lymphoma" 15 . Further characterization of this tumor revealed angiocentric infiltration of tumor cells, and the terminology of "angiocentric T-cell lymphoma" was proposed $^{16-18}$. In the REAL Classification, this type of nasal lymphoma was considered an angiocentric lymphoma, together with pulmonary lymphomatoid granulomatosis of Bcell origin, based on morphological features ${ }^{3}$. However, Suzumiya et al. demonstrated that tumor cells of this nasal lymphoma express cytoplasmic CD3 and CD56, but not Tcell receptors, suggesting their NK-cell origin ${ }^{19}$. On November 11-14, 1994, a workshop on NK-cell lymphomas was held in Hong Kong ${ }^{20}$. At this meeting, tumor angiocentricity was not considered an absolute characteristic of nasal NKcell lymphomas, and similarities with non-nasal NK-cell lymphomas were confirmed. Thus, the nomenclature of "nasal and nasal-type T/NK-cell lymphoma" was employed. In the WHO Classification, the extranodal origin of this lymphoma was emphasized, and the terminology "extranodal NK/T-cell lymphoma (ENKL), nasal-type" was adopted ${ }^{4}$.

\section{Clinical characteristics of aggressive NK-cell leukemia}

ANKL is characterized by the systemic proliferation of NK-cells, with a highly aggressive clinical course. It

\begin{tabular}{|c|c|c|}
\hline & NK-cell leukemia & NK-cell lymphoma \\
\hline Original terminology & Aggressive NK-cell leukemia (1986) & Nasal T-cell lymphoma (1982) \\
\hline Alternative nomenclature & $\begin{array}{c}\text { Aggressive LGL leukemia } \\
\text { Non-T LGL leukemia } \\
\text { NK-LGL leukemia }\end{array}$ & $\begin{array}{l}\text { Angiocentric T-cell lymphoma } \\
\text { Nasal NK-cell lymphoma }\end{array}$ \\
\hline REAL Classification (1994) & LGL leukemia, NK-cell type & Angiocentric lymphoma \\
\hline $\begin{array}{l}\text { Hong Kong Workshop } \\
\text { Report (1996) }\end{array}$ & & $\begin{array}{l}\text { Nasal and nasal-type } \\
\text { T/NK-cell lymphoma }\end{array}$ \\
\hline WHO Classification (2001) & Aggressive NK-cell leukemia & $\begin{array}{l}\text { Extranodal NK/T-cell lymphoma, } \\
\text { nasal-type }\end{array}$ \\
\hline Lugano Meeting (2005) & Generic NK-cel & nphoma (?) \\
\hline
\end{tabular}

Fig. 1. History of NK-cell leukemia/lymphoma nomenclature. The classification and nomenclature of NK-cell leukemia and lymphoma have changed over time, and different classification schemes have been proposed. Aggressive NK-cell leukemia and extranodal NKcell lymphoma, nasal-type are separate entities in the new WHO Classification, and the "generic NK-cell lymphoma" category was recently proposed to integrate these two diseases by Weisenbuerger in the 9th International Conference on Malignant Lymphoma 2005. 
Table 2. Phenotypic profile of NK-cell neoplasms and other related/CD56 ${ }^{+}$T-cell lymphomas

\begin{tabular}{|c|c|c|c|c|c|}
\hline & $\begin{array}{c}\text { Aggressive } \\
\text { NK-cell leukemia }\end{array}$ & $\begin{array}{c}\text { Extranodal } \\
\text { NK- cell lymphoma }\end{array}$ & $\begin{array}{c}\text { Hepatosplenic } \\
\text { T- cell lymphoma }\end{array}$ & $\begin{array}{l}\text { Enteropathy-type } \\
\text { T-cell lymphoma }\end{array}$ & T-LGL leukemia \\
\hline $\mathrm{CD} 2$ & + & + & + & + & + \\
\hline sCD3 & - & - & + & + & + \\
\hline cyCD3 & + & + & + & + & + \\
\hline CD4 & - & - & - & - & - \\
\hline CD5 & - & - & $+1-$ & - & + \\
\hline CD7 & $+1-$ & $+1-$ & $+1-$ & + & + \\
\hline $\mathrm{CD} 8$ & $+1-$ & $+/-$ & $+1-$ & + & $+/-$ \\
\hline CD16 & $+(/-)$ & - & $+/-$ & - & - \\
\hline CD43 & + & + & + & + & + \\
\hline CD45RO & + & + & + & + & + \\
\hline CD56 & + & + & $+(/-)$ & $+1-$ & - \\
\hline CD57 & - & - & $-(/+)$ & - & + \\
\hline TCR & - & - & + & $+/-$ & + \\
\hline Granzyme B & + & + & $+1-$ & + & - \\
\hline TIA- 1 & + & + & + & + & - \\
\hline EBV & + & + & - & - & - \\
\hline
\end{tabular}

accounts for less than $1 \%$ of lymphoid malignancies in $\mathrm{Japan}^{21}$, and is also rare in Hong Kong, Korea and Taiwan (personal communications). The NK-cell Tumor Study Group in Japan reported the largest series in the literature, examining 22 patients ${ }^{22}$. When data from several reports are considered together, ANKL predominantly occurs in younger patients with a median age around 40 years without any sex predilection $^{12,14,22-32}$. Patients frequently present with Bsymptoms, such as fever, night sweat or weight loss, and hematological findings are consistent with leukemia, including circulating and bone marrow leukemic cells, neutropenia, anemia and thrombocytopenia. Hepatosplenomegaly frequently occurs, but does not affect all patients. Cutaneous or central nervous system involvement is uncommon. Interestingly, hypersensitivity to mosquito bites is sometimes a preceding feature of NK-cell leukemia, particularly in younger patients $^{33-35}$. Additionally, leukemic progression of nasal NK-cell lymphoma was also reported ${ }^{36}$. Leukemic cells exhibit a LGL morphology, surfaceCD3 ${ }^{-} \mathrm{CD} 2^{+} \mathrm{CD} 56^{+}$immunophenotype, and germline configurations of T-cell receptor genes ${ }^{22,23,29}$. CD16 and cytoplasmic CD3 are positive in many cases. Expression of CD122 and the lack of CD25 suggest ANKL cells originate as cytotoxic NK-cells ${ }^{22}$, rather than immunoregulatory NK-cells ${ }^{7}$. As with ENKL of nasal type, tumor cells are Epstein-Barr virus (EBV) positive 22-24,27,29-31. Although no recurrent cytogenetic abnormalities have been identified, alterations in chromosome 7 occur relatively frequently in $\mathrm{ANKL}^{22}$. Chemotherapy for acute leukemia or aggressive lymphoma is not highly effective, resulting in poor prognosis for this disorder. Resistance to chemotherapy is likely mediated by p-glycoprotein, a product of MDR1 gene ${ }^{37}$, that is expressed in this type of lymphoma ${ }^{38-40}$. Most affected patients die within 2 years, many within 6 months after diagnosis ${ }^{22,23}$.

\section{Clinical characteristics of extranodal NK-cell lympho- ma, nasal type}

ENKL is characterized by extranodal involvement, particularly the nasal/paranasal area, and is referred to as "nasal NK-cell lymphoma" in this situation. ENKL is rare in Western countries, but is more frequent in East Asia and Central and South America ${ }^{41-46}$. It represents $3.3 \%$ of all nonHodgkin's lymphoma in Japan ${ }^{21}, 6 \%$ in Hong Kong ${ }^{47}, 8 \%$ in Korea $^{48}$, and $5 \%$ in Taiwan ${ }^{49}$. ENKL predominantly occurs in middle-aged patients, and it is significantly more prevalent in men. This type of lymphoma, particularly advanced-stage cases, is associated with hemophagocytic syndrome, and some patients develop the sudden onset of pancytopenia or multi organ failure $e^{41-45}$. Histopathologically, the lymphoma cells are polymorphous and show an angiocentric growth pattern, with subsequent vascular obstruction and prominent necrosis. The immunophenotype of tumor cells resembles that of NK-cells (surfaceCD3 ${ }^{-}$cytoplasmicCD3 $\varepsilon^{+} \mathrm{CD} 56^{+}$) in 


\section{R. Suzuki}

most cases ${ }^{19,50-52}$, but, in rare circumstances, is more consistent with a T-cell phenotype. Most ENKL cells also express cytotoxic granule-associated proteins, such as perforin, granzyme B, TIA-1, and granzyme $\mathrm{M}^{53-59}$. Increased expression of Fas-ligand is commonly seen in ENKL, but this is nonspecific and seen in a number of aggressive lymphomas ${ }^{55,60-62}$. NK inhibitory receptors, such as CD94 or NKG2A are also expressed in NK-cell neoplasms, but such expression is not uniform or consistent ${ }^{63-67}$. However, expression of CD94 is reported to confer a better prognosis in $\mathrm{ENKL}^{67}$. $\mathrm{EBV}$ is found in the tumor cells in virtually all cases, and ENKL, nasal-type is now regarded as an EBV-related neoplasm ${ }^{68-70}$. Deletions of the long arm of chromosome 6 are frequently seen in ENKL ${ }^{71,72}$, but this abnormality is also commonly seen in other types of lymphoma ${ }^{73,74}$. Approximately $70 \%$ of ENKL patients present with limited stage I or II disease ${ }^{52,75-82}$. In addition to the paranasal area, tumors frequently occur in the skin and soft tissue ${ }^{29,83-90}$. Regional lymph nodes may be involved, but restriction to nodal disease is extremely rare ${ }^{91}$. The clinical course of NK-cell lymphoma varies with the clinical stage. Patients with limited stage disease (usually nasal disease) typically have an indolent course with tumor restriction to the original site, but others suffer rapid progression to systemic dissemination often accompanied by hemophagocytosis or disseminated intravascular coagulation. Radiotherapy is effective in the treatment of ENKL, but, as with ANKL, chemotherapy is of limited effectiveness due to the expression of p-glycoprotein ${ }^{37-40}$, which mediates the ac- tive transport of anthracyclines and vinca alkaloids. Therefore, radiotherapy is typically undertaken in patients with limited stage diseases ${ }^{92-101}$, with or without subsequent chemotherapy. No effective therapies exist for advanced cases, however.

\section{Putative precursor NK-cell neoplasms}

At the Hong Kong Workshop for Extranodal T/NK-cell lymphoma in 1994, Drs. Suchi and Mori presented two previously unrecognized forms of CD56-positive lymphoma ${ }^{20}$. These cases were characterized by unusual skin involvement, blastic morphology, $\mathrm{sCD}^{-} \mathrm{CD}^{-} 6^{+} \mathrm{TdT}^{+}$phenotype without B-cell markers, and the lack of Epstein-Barr virus (EBV), and the nomenclature of "blastic NK-cell lymphoma" was assigned to this disease ${ }^{20}$. There are several reports of this type of lymphoma, which were not specifically diagnosed due to their unusual phenotype that is not consistent with a clear cellular origin ${ }^{87-89,102-108}$. These tumors were hypothesized to originate from precursor NK-cells due to their phenotypic similarity (Fig. 2), but many blastic NK-cell lymphoma (BNKL) express CD4 ${ }^{87-89,104-108}$. Recently, many clinicopathologic differences between CD4-positive and -negative BNKL have been described, suggesting that these two subgroups constitute distinct diseases ${ }^{109,110}$. However, it remains unclear whether CD4 expression or anatomic location (i. e., cutaneous vs. non-cutaneous) should be the primary factor determining categorization. Occasionally, leukemic cases of

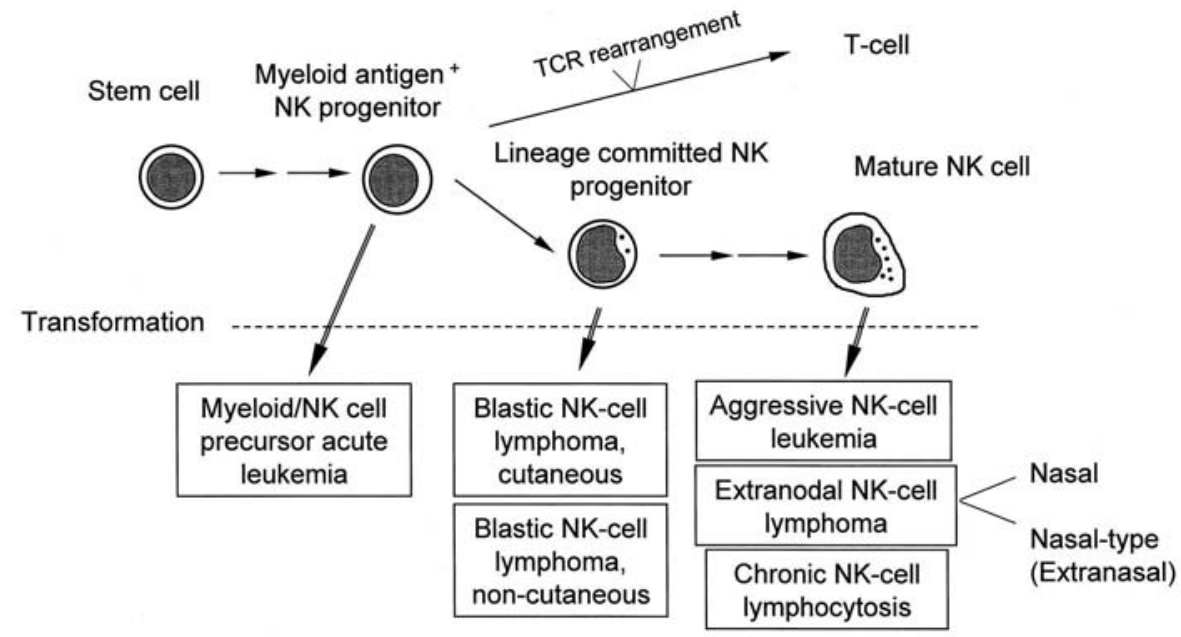

Fig. 2. Differentiation pathway of NK-cells and corresponding NK-cell neoplasms.

NK-cells differentiate from stem cells through the myeloid antigen positive NK/ T bi-potential progenitor and the lineage committed progenitor. The myeloid/NK cell precursor acute leukemia originates from the myeloid antigen positive progenitor, and blastic NK-cell lymphoma are derived from a relatively mature, NK-cell lineage committed progenitor. Mature NK-cell neoplasms, aggressive NK-cell leukemia, extranodal NK-cell lymphoma of nasal and extranasal origin, and chronic NK-cell lymphocytosis arise from transformed mature NK-cells. 
this tumor have been reported ${ }^{111-116}$, but no prominent clinicopathologic differences between the leukemic and lymphomatous types have been identified ${ }^{110}$. Several groups have proposed that $\mathrm{CD}^{+} \mathrm{BNKL}$ arise from the precursors of plasmacytoid dendritic cells (pDCs) ) $^{117,118}$ or plasmacytoid monocytes ${ }^{119}$, on the basis of CD123 expression and interferon production by the tumor cells. However, pDCs are normally present in lymph node and are rare in the skin. Additionally, CD56 is not expressed on normal pDCs ${ }^{120,121}$ except for a very minor population ${ }^{122,123}$, and CD123, which is expressed on a variety of normal and malignant hematopoietic cells is not a specific marker for $\mathrm{pDCs}^{124,125}$. $\mathrm{CD}^{+/-} \mathrm{CD}^{-}$ $\mathrm{CD} 123^{+}$leukemia/lymphoma with pDC features is the real pDC malignancy ${ }^{126,127}$. Thus, the true origin of BNKL needs further studies.

In 1997, another type of immature CD56-positive hematologic tumor was identified as "myeloid/NK cell precursor acute leukemia" (Fig. 2) ${ }^{128}$. This leukemia was characterized by pronounced extramedullary involvement, immature lymphoblastoid cellular morphology without myeloperoxidase reactivity, a $\mathrm{CD} 7^{+}, \mathrm{CD} 33^{+}$, and $\mathrm{CD} 56^{+}$phenotype, myeloid chemosensitivity and poor prognosis. These cases were classified as AML M0 according to the FAB classification ${ }^{129,130 \text {, }}$ and were distinct from CD56-positive tumors of myeloid/NK cell acute leukemia with mature promyelocytoid morphology ${ }^{131}$, as well as BNKL ${ }^{99}$. However, this form of leukemia was later found to exhibit different clinical characteristics from $\mathrm{CD}^{-}$or $\mathrm{CD} 56^{-} \mathrm{AML} \mathrm{M} 0^{132}$, and was thus a distinct disease entity among AML subclasses.

These CD56-positive immature leukemia/lymphomas are included in the NK-cell Tumor Study Group classification scheme, but have not yet been shown to originate from precursor NK-cells. Strictly, these diseases should be regarded as CD56-positive immature hematolymphoid tumors, but the phenotypic similarities to NK-cell precursors may facilitate our understanding of these tumors. The NK-cell Tumor Study Group has proposed a provisional classification scheme of NK-lineage malignancies including these ill-defined diseases $^{44,133}$.

\section{Other CD56-positive malignancies to be differentially diagnosed}

CD56 is not a specific NK-cell marker, and several CD56-positive tumors have been identified (Table 3). In acute myeloid leukemia (AML), CD56 is expressed in approximately $20 \%$ of cases, particularly those of the monocytic lineage ${ }^{134-136}$. Although AML is a heterogeneous disease, the expression of CD56 suggests a poor prognosis in AML in general $^{137-139}$, or for several specific subtypes ${ }^{140-144}$. CD56 was first reported as a prognostic factor for patients with AML M2 with the $\mathrm{t}(8 ; 21)(\mathrm{q} 22 ; \mathrm{q} 22)$ translocation $^{140}$, but this has not been verified by other groups. In the meantime, several groups have shown the prognostic significance of CD56 expression in acute promyelocytic leukemia with the $\mathrm{t}(15 ; 17)(\mathrm{q} 22 ; \mathrm{q} 21)$ translocation ${ }^{141-144}$. Differentiation of nonnasal NK-cell lymphomas occurring in the skin or soft tissue from extramedullary AML is particularly important for prognostic and therapeutic decisions. However, in acute lymphoblastic leukemia CD56 expression is relatively rare ${ }^{134,145-147 .}$.

CD56 is also expressed in a subset of T-cells, as well as $5-20 \%$ of peripheral T-cell lymphomas ${ }^{148-153}$. Some conditions have been described as "NK-like T-cell lymphoma" $86,90,154,155$, but this label does not accurately reflect the T-lymphocyte origin of this lymphoma and was therefore not included in the current WHO classification ${ }^{156}$. Because NK-cell and T-cell lymphomas share the $\mathrm{cyCD}^{+} \mathrm{CD}^{+} 6^{+}$phenotype, and the expression of $\mathrm{sCD} 3$ and cyCD3 is usually indistinguishable on paraffin sections, appropriate diagnosis is

Table 3. CD56-positive tumors other than NK-cell lineage

\begin{tabular}{llll}
\hline \multicolumn{1}{c}{ Category } & Frequency & \multicolumn{1}{c}{ Subtype } & \multicolumn{1}{c}{ Significance of CD56 expression } \\
\hline Acute myeloid leukemia & $20 \%$ & Monocytic leukemia (FAB M4/M5) & \\
& & M2 with $\mathrm{t}(8 ; 21)$ & Possible prognostic factor \\
& & Acute promyelocytic leukemia & $\begin{array}{l}\text { Prognostic factor } \\
\text { Peripheral T-cell lymphoma }\end{array}$ \\
& $5-10 \%$ & Anaplastic large cell lymphoma & Possible prognostic factor \\
& & Peripheral T-cell lymphoma, unspeci- & Not prognostic \\
& fied & Not prognostic \\
Multiple myeloma & $50-70 \%$ & & \\
Small round cell tumor & Most cases & Neuroblastoma & \\
& & PNET & \\
& Ewing sarcoma & \\
& Wilms tumor & \\
& Rhabdomyo sarcoma & \\
& Small cell lung cancer & \\
& &
\end{tabular}




\section{R. Suzuki}

essential ${ }^{50,51,157}$. Cells derived from hepatosplenic T-cell lymphoma and enteropathy-type T-cell lymphoma are usually CD56 positive (Table 2) ${ }^{150,158-161}$ but other T-cell lymphomas do not display consistent CD56 expression. On the other hand, CD56 expression is a strong prognostic factor for anaplastic large cell lymphoma ${ }^{152}$, but not peripheral T-cell lymphoma, unspecified ${ }^{153}$.

As CD56 is a neural cell adhesion molecule, it is also expressed in non-hematologic tumors, including neuroectodermal tumors. Its expression has been documented in neuroblastoma ${ }^{162,163}$, PNET ${ }^{162}$, Ewing sarcoma ${ }^{162}$, Wilms tumor $^{164}$, rhabdomyosarcoma ${ }^{162}$, malignant schwannoma ${ }^{163}$ and small cell lung cancer ${ }^{165,166}$. As these tumors can also exhibit a small round morphology, proper exclusion of these tumors from the differential diagnosis is essential.

\section{Genetic features and oncogenes}

Currently, no genetic abnormalities specific for NKlineage neoplasms have been identified. Deletion of the long arm of chromosome 6 was reported to be the most frequent cytogenetic aberration ${ }^{71,72}$, but no target or tumor suppressor genes have been identified in this region to date ${ }^{167-169}$. Additionally, no consistent oncogenes or tumor suppressors have been identified for NK-cell lymphoma (Table 4). Homozygous deletion of p15 and p16/p14 were identified in approximately $30 \%$ of the cases studied ${ }^{170,171}$, and mutation of the FAS gene $^{172,173}$ and methylation of $\mathrm{p} 73^{174}$, SHP $1^{175}$, $\mathrm{hMLH} 1{ }^{176}, \mathrm{p} 16^{176}$, and RAR $\beta^{176}$ have been identified in more than half of the cases. Mutation of $\beta$-catenin ${ }^{177-179}$ and methylation of $\mathrm{p} 21$ and $\mathrm{p} 15$ were observed less frequently ${ }^{177,180}$, but mutation of $N / K / H-R A S$ and $N / c-M Y C$ genes were found in only a small minority of cases ${ }^{171,177-179}$. Ethnicity also affects genetic alterations in NK-cell lymphoma including differences between Japanese and Chinese pa- tients for $\mathrm{p} 73^{174,180}, \mathrm{p} 53^{178,179,181}$, and $\mathrm{c}-\mathrm{Kit}^{182}$ alterations. A more precise characterization of the genetic changes associated with NK-cell lymphoma, as well as any role for EBV infection, needs further clarification.

Complementary genetic hybridization $(\mathrm{CGH})$ has been used to investigate genetic aberrations in NK-cell lymphoma ${ }^{175,183-186}$. These studies identified the gain of $1 \mathrm{p}$, 6p, 11q, 12q, 17q, 19p, 20q and Xp, and the loss of 6q, 11q, $13 q$ and $17 p$ in several different samples, but several differences were also identified between the cases examined. Recently, an array-based CGH study was performed and identified new gain/loss regions, which could not be identified using conventional CGH analyses ${ }^{187}$. This study also demonstrated clear genetic difference between ANKL and ENKL, suggesting that these are two distinct disease entities. This data supports the clinicopathologic features identified between ANKL and ENKL ${ }^{188}$. These differences may represent differences in ENKL between localized and advanced cases, but further studies are needed to clarify this issue.

\section{Epstein-Barr virus (EBV)}

In most mature NK-cell leukemias and lymphomas, clonal EBV proliferation has been found in tumor cells $^{23,24,41-44,68,189,190}$. Most tumors are associated with EBV with latency II with the occasional absence of LMP-1 ${ }^{30,191,192}$. Binding of EBV to target cells is mediated by CD21 in Bcells ${ }^{193}$ and NK/T-cells ${ }^{194}$, but recent studies suggest the existence of other binding pathways, particularly in epithelial cells $^{195}$. Although the EBV-receptor remains unclear in CD21-negative NK-cell tumors, human leukocyte antigen class II $\beta$ plays an important role for the internalization of EBV in NK-cells ${ }^{196}$. The EBV genome is linear in the viral particles, but circularizes in an episomal form after infection with a uniquely sized terminal repeat ${ }^{197}$. Therefore, EBV can

Table 4. Aberrations of oncogenes in NK-cell leukemia/lymphoma

\begin{tabular}{llll}
\hline \multicolumn{1}{c}{ Gene } & \multicolumn{1}{c}{ Type of aberration } & \multicolumn{1}{c}{ Frequency } & \multicolumn{1}{c}{ Reference } \\
\hline$p 73$ & Methylation & $94 \%$ (China, Hong Kong), 10\% (Japan) & 174,180 \\
$h M L H 1$ & Methylation & $60-70 \%$ (China, Hong Kong) & 176 \\
$R A R b$ & Methylation & $56 \%$ & 176 \\
SHIP1 & Methylation & $91 \%$ & 175 \\
$p 16$ & Methylation & $63 \%$ & 176 \\
$p 15$ & Methylation & $48 \%$ & 176 \\
$p 15 / p 16$ & Homozygous deletion & $38 \%$ & 170,171 \\
Fas & Mutation & $50-60 \%$ & 172,173 \\
$p 53$ & Mutation & $20-60 \%$ & $178,179,181$ \\
$c-$ KIT & Mutation & $5-71 \%$ (China), 16-22\% (Japan) & 178,182 \\
$b-$ catenin & Mutation & $16-30 \%$ & $177-179$ \\
N/K/H-Ras & Mutation & Rare (<5\%) & $171,177-179$ \\
N/c-Myc & Amplification/ Mutation & None & 171 \\
\hline
\end{tabular}


be detected by Southern blotting as a single band, but genomic integration of EBV occurs in approximately $10 \%$ of the cases ${ }^{198}$. Meanwhile, biclonal or polyclonal EBV genomes are found in occasional cases, and the lytic phase of EBV infection has been seen in some overlapping cases. HANK-1 is a cell line established from tumor cells of disseminated NKcell lymphoma ${ }^{199}$. Southern blot analysis using a probe specific for the EBV terminal repeat demonstrated that this cellline was derived from a minor clone in original tumor cells (Fig. 3). In most cases, isolated tumor cells have the same phenotype of typical NK-cell neoplasms, suggesting a common tumor origin with differential EBV clonality. Because the EBV genome exists within cells as an episome without integration in most cases, cellular reinfection is possible causing the appearance of different EBV clones. This has been demonstrated in other $\operatorname{cases}^{167,200,201}$, and therefore, EBV monoclonality is not always required for the diagnosis of NKcell malignancies.

The presence of EBV-DNA in the serum/plasma of patients was first recognized in nasopharyngeal carcinoma using polymerase chain reaction $(\mathrm{PCR})^{202}$. Later, it was also found in other EBV-associated tumors including NK-cell lymphoma ${ }^{203}$. Spontaneous death of tumor cells leads to the release of EBV DNA, and the presence of EBV DNA in the serum does not necessarily indicate the presence of active EBV in the circulating blood. Therefore, the upper size limit of detectable EBV-DNA is $500 \mathrm{bp}$, and the size less than 300

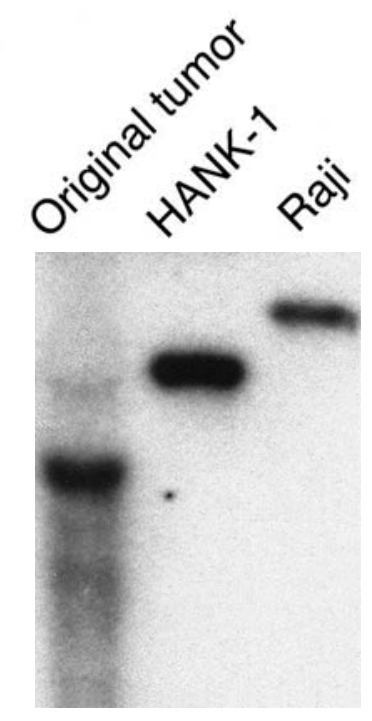

Fig. 3. Southern blotting of EBV terminal repeat in the HANK-1 cell line.

Southern blot analysis was performed using a probe targeting the EBV terminal repeat. The nasal-type NK-cell lymphoma cell line HANK-1 was derived from a minor lymphoma clone, which differed from the major clone in the size of the EBV terminal repeat. Monoclonality with respect to EBV is not always required for the diagnosis of extranodal NK-cell lymphoma. bp is desirable for diagnosis or detection of minimal residual disease $^{204}$. Infection-competent EBV is found in the lymphocytes of patients with acute or chronic EBV infection ${ }^{205}$, and PCR using peripheral mononuclear cells or whole blood is applied for these patients ${ }^{206}$. Although this is a more sensitive method than serum/plasma $\mathrm{PCR}^{207,208}$, it is not suitable because it can also detect bystander EBV in immunocompromised patients. A prospective study comparing the prognostic significance between plasma and whole blood as templates for real-time PCR is now under way.

\section{Cell lines}

After the initial recognition of NK-cell leukemia/ lymphoma, many cell lines were established from primary tumors that have been invaluable research tools ${ }^{209,210}$. The cell lines derived from NK-cell neoplasms and related disorders are listed in Table $5^{10,199,200,211-220}$. The first NK-cell tumor line was established by Yodoi et al. in 1983 from a boy with mediastinal lymphoblastic lymphoma ${ }^{211}$. Although much relevant clinical information from this case was not provided, the diagnosis according to the current classification scheme seems to fall within the category of ENKL. Likewise, various diagnostic terms were used in the original description of different cell lines, but all can be sorted into three categories, ANKL cell lines ${ }^{10,212-214,217,220}$, ENKL cell lines $^{199,200,211,215,218,219}$, and other NK-cell lines ${ }^{216,219}$. Several NK-cell lines with abnormal karyotypes have been established from patients without defined malignancies, such as hypersensitivity to mosquito bite, chronic active EBV infection (CAEBV) and hydroa vacciniforme-like eruption. The ability to establish cell lines from these patients supports the hypothesis these diseases are premalignant conditions that may progress to NK-cell leukemia/lymphoma. Most of these cell lines were established from Japanese patients, and are phenotypically similar to the original neoplasms, being positive for CD56 and EBV, and IL-2 dependent. Cell lines derived from ENKL and other categories were all established from Japanese patients and are uniformly positive for CD56 and EBV. In contrast, several lines were established from non-Oriental subjects, and these are occasionally negative for $\mathrm{CD} 56^{213,214}$ or $\mathrm{EBV}^{217,220}$. Existence of CD56 may not be essential for the leukemogenesis of NK-cell leukemia. The absence of EBV is consistent with a diagnosis of ANKL and further differentiates it from ENKL $22,25,28,32$. These cell lines are faithful replicas of the actual in vivo NK-cell leukemias/ lymphomas. Further studies, particularly genetic investigations, on these cell lines will provide invaluable information on the diagnosis and treatment of NK-cell neoplasms.

\section{Relationship to chronic active EBV infection}

CAEBV is a peculiar situation mainly occurs in children 
Table 5. Cell lines derived from $\mathrm{NK}$-cell neoplasms and related disorders.

\begin{tabular}{|c|c|c|c|c|c|c|c|}
\hline Cell line & Age, sex & Ethnicity & Original description of disease & CD56 & EBV & $\begin{array}{l}\text { Cytokine } \\
\text { dependency }\end{array}$ & Ref. \\
\hline \multicolumn{8}{|c|}{ Aggressive NK-cell leukemia cell line } \\
\hline (Unnamed) & $71 \mathrm{M}$ & White & Aggressive NK-cell leukemia & ND & ND & IL-2 & 10 \\
\hline NK-92 & $50 \mathrm{M}$ & Unknown & LGL-NHL with BM involvement & + & + & IL-2 & 212 \\
\hline TKS-1 & $21 \mathrm{M}$ & Japanese & Aggressive LGL leukemia & $-*$ & ND & IL-2 & 213 \\
\hline NKL & $62 \mathrm{M}$ & White & NK-LGL leukemia & $-*$ & - & IL-2 & 214 \\
\hline KYHG-1 & $45 \mathrm{~F}$ & Japanese & Aggressive NK-cell leukemia & + & - & IL-2 & 217 \\
\hline IMC-1 & $42 \mathrm{M}$ & Native American & Aggressive NK-cell leukemia & + & - & IL-2 & 220 \\
\hline \multicolumn{8}{|c|}{ Extranodal NK-cell lymphoma cell line } \\
\hline YT & $15 \mathrm{M}$ & Japanese & Acute lymphoblastic lymphoma with thymoma & + & + & No & 211 \\
\hline HANK-1 & $46 \mathrm{~F}$ & Japanese & Nasal-type NK-cell lymphoma & + & + & IL-2 & 199 \\
\hline NK-YS & $19 \mathrm{~F}$ & Japanese & Nasal NK-cell lymphoma & + & + & IL- 2 & 215 \\
\hline SNK- 1 & $24 \mathrm{~F}$ & Japanese & Nasal NK-cell lymphoma with CAEBV & + & + & IL- 2 & 200 \\
\hline SNK-3 & $44 \mathrm{M}$ & Japanese & Nasal NK- cell lymphoma & + & + & IL- 2 & 219 \\
\hline SNK- 6 & $62 \mathrm{M}$ & Japanese & Nasal NK-cell lymphoma & + & + & IL- 2 & 218 \\
\hline \multicolumn{8}{|c|}{ Other NK-cell line } \\
\hline $\mathrm{KAI} 3$ & $13 \mathrm{M}$ & Japanese & Hypersensitivity to mosquito bite & + & + & IL- 2 & 216 \\
\hline SNK- 5 & $14 \mathrm{~F}$ & Japanese & CAEBV & + & + & IL- 2 & 219 \\
\hline SNK- 10 & $17 \mathrm{M}$ & Japanese & CAEBV & + & + & IL- 2 & 219 \\
\hline SNK- 11 & $16 \mathrm{~F}$ & Japanese & Hydroa vacciniforme- like eruption & + & + & IL- 2 & 219 \\
\hline
\end{tabular}

* CD56 was positive in the patients' original leukemic cells.

or young adults with waxing and waning symptoms s $^{205,221-223}$. Most patients present with fever, fatigue, lymphadenopathy and/or hepatosplenomegaly, and the EBV genome can be found in peripheral lymphocytes. These symptoms resolve with or without treatments such as anti-inflammatory drugs or steroids but recur after months or years. Occasionally, bona fide NK- or T-cell malignancies develop, and pursue fatal clinical course $\mathrm{e}^{201,224}$. Etoposide-containing chemotherapy is effective $^{225}$ and a cure can be obtained with hematopoietic stem cell transplant ${ }^{192,226}$, but the timing of treatment is difficult because of the fluctuating clinical course. CAEBV is not simply an EBV infection, but it represents an indolent lymphoproliferative disorder. Young patients with CAEBV need careful observations to judge the timing of treatment. In the future, optimal therapeutic strategies for CAEBV need to be further explored.

CAEBV typically develops in younger patients after an initial EBV infection, but cases in older individuals are sometimes reported ${ }^{219,223,224,227}$. The diagnosis of such cases relies on the presence of the EBV genome in peripheral blood as detected by PCR. However, the EBV genome is also present in the plasma of patients with EBV-positive malignancies including NK-cell neoplasms, and often indicates of the presence of occult malignancies, particularly in older patients. A comprehensive examination for malignancies is essential in elderly patients before a confident diagnosis of CAEBV can be made.

\section{Chronic NK-lymphocytosis}

Chronic NK-lymphocytosis (CNKL) is characterized by a chronic increase in the number of peripheral blood NK-cells without lymphadenopathy or organomegaly $^{14,42,228,229}$. Clinically, the disease presents with an indolent course, and no cytogenetic abnormalities are usually found. Although the disease itself has uncertain malignant potential, rare cases may develop into ANKL ${ }^{230-232}$. However, this may represent the presence of occult ANKL miscategorized as CNKL rather than transformation. Therefore, careful observation is needed for CNKL patients. Because EBV is not usually found in CNKL, testing for EBV may facilitate the differential diagnosis ${ }^{233}$. Seroreactivity to 
HTLV-II has been reported in $\mathrm{CNKL}^{234}$, but no evidence of viral DNA was found in the increased NK-cells ${ }^{235}$. CNKL is also associated with reactive conditions against viral infections or underlying solid tumors ${ }^{14,228}$. Careful whole-body examination is therefore recommended during the clinical management of patients with CNKL.

\section{Therapy for localized extranodal NK-cell lymphoma}

Radiotherapy alone has been used for the treatment of limited stage of ENKL ${ }^{92,95,97}$, but the 5-year overall survival (OAS) is approximately $50 \%$. In other subtypes of nonHodgkin's lymphoma of similar clinical stage, 3 to 4 courses of chemotherapy followed by radiotherapy is now a standard therapy with 5-year overall survival rates of more than $80 \%{ }^{236,237}$. However, this strategy is not effective for the treatment of NK-cell lymphoma. The 5-year overall survival rate is around $40 \%$, which is comparable to or lower than the survival rate seen with radiotherapy alone ${ }^{73,75,84,94,95,97}$.

Recently, several groups have treated patients with irradiation of more than 45 to 50 Gy followed by short courses of chemotherapy, and the reported 5-year OAS of this procedure reaches $70 \%{ }^{93,95-97}$. However, the initial radiotherapy may miss underlying minimal lesions outside the radiation field. Therefore, a strategy of simultaneous chemoradiotherapy, as used for solid tumors, such as esophageal, laryngeal and lung cancers, may be beneficial for the treatment of ENKL ${ }^{238-240}$. Currently, the Japanese Clinical Oncology Study Group is performing a prospective evaluation for localized nasal NK/Tcell lymphoma.

\section{Therapy for ANKL or advanced ENKL}

Most patients with advanced disease tend to be treated with chemotherapy, such as CHOP (cyclophosphamide, doxorubicin, vincristine, prednisone) or third generation anthracycline-containing regimens, but most patients respond poorly and die within several months. Several reports demonstrated successful treatment using hematopoietic stem cell transplantation (HSCT) for these diseases ${ }^{241-252}$. Currently, HSCT is the only therapy expected to be curative in advanced cases. However, the results of transplant during relapse are poor, and this requires the development of more effective chemotherapeutic regimens for NK-cell neoplasms.

Aviles et al. described an active combination chemotherapy for advanced nasal NK/T-cell lymphoma, CMED (cyclophosphamide $2 \mathrm{~g} / \mathrm{m}^{2}$ and methotrexate $200 \mathrm{mg} / \mathrm{m}^{2}$ on day 1 , etoposide $300 \mathrm{mg} / \mathrm{m}^{2}$ on day 1 and 2 , and dexamethasone 20 $\mathrm{mg} / \mathrm{m}^{2}$ on day 1 to 4 , supplemented by granulocyte colony stimulating factor on day 2 to 13$)^{253}$. They treated 32 patients of stage III/IV disease with three courses of CMED therapy with an interval of two weeks, accompanied by 50 Gy irradiation of the nasal area and another three courses of CMED therapy. The complete remission rate and actuarial 5-year overall and disease free survival rates were $65 \%$, but no other reports using this treatment regimen have been published. Yong et al. achieved good results with another novel chemoradiotherapy using L-asparaginase $6,000 \mathrm{IU} / \mathrm{m}^{2}$ and dexamethasone $10 \mathrm{mg} /$ body on days 1 to 7 , and vincristine 1.4 $\mathrm{mg} / \mathrm{m}^{2}$ on day $1^{254}$. Although the treatment schedule was not uniform, $18 \mathrm{CHOP}$ refractory patients were treated with this regimen from one to six courses with intervals of 21 to 28 days, followed by radiotherapy of 50 to 70 Gy (median : 56 Gy). In addition, several case reports claim an excellent efficacy of L-asparaginase in the treatment of refractory NKcell malignancies ${ }^{246,255,256}$.

Recently, the NK-cell Tumor Study Group started a phase I trial of a new combination chemotherapy named SMILE. The SMILE regimen consists of a steroid hormone, methotrexate, ifosfamide, L-asparaginase and etoposide, and is a dose-finding study for methotrexate and etoposide (Fig. 4). Methotrexate is administered on the first day, and etoposide and ifosfamide are given from the day after. This schedule is based on in vitro pharmacokinetic studies by Kano et $a l^{257,258}$, including unpublished observations. They showed an additive effect of etoposide and ifosfamide when administered on simultaneous days and a synergistic effect of methotrexate when given before these two agents. When methotrexate and other drugs are used simultaneously, they are antagonistic. The toxicity and efficacy of SMILE therapy are now being prospectively evaluated.

\section{Conclusion}

Mature NK-cell tumors arise as two distinct entities, ANKL and ENKL. Clear differences exist between these conditions, but ANKL and stage IV ENKL can clinically be managed with the same therapeutic strategy. The mechanism of tumorgenesis remains unclear for both ANKL and ENKL,

Day 1 Day 2, 3, 4 Day 8, 10, 12, 14, 16, 18, 20

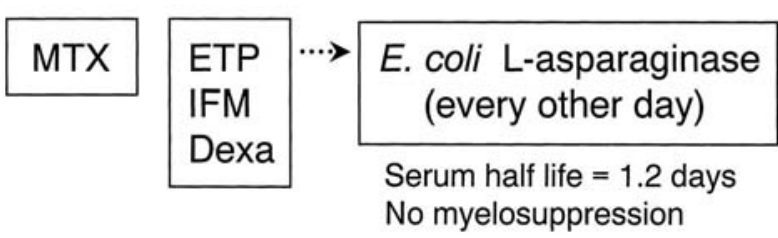

Fig. 4. Summary of SMILE chemotherapy Methotrexate is given on the initial day of SMILE chemotherapy, accompanied by a 3-day course of etoposide, ifosfamide and dexamethasone (days 2-4). Because of the absence of myelosuppressive adverse reaction and a half-life of 1.3 days, L-asparaginase will be given on every other days from day 8 to day 20 ( 7 doses). The SMILE therapy will be repeated with an interval of 28 days. Doses of each agent will be determined in a prospective dose-escalation study. 


\section{R. Suzuki}

and future studies are needed to clarify the molecular pathology of these diseases. Unfortunately, the prognoses of these malignancies are poor for both limited and advanced diseases, and new therapeutic modalities are needed to effectively treat patients. Appropriate therapeutic strategies should be explored in ongoing prospective studies.

\section{ACKNOWLEDGMENTS}

I would like to thank Drs. Kazuo Oshimi (Juntendo University School of Medicine) and Motoko Yamaguchi (Mie University School of Medicine) for critical reading of this manuscript.

\section{References}

1 The Non-Hodgkin's Lymphoma Pathologic Classification Project : National Cancer Institute sponsored study of classification of nonHodgkin's lymphomas : Summary and description of Working Formulation for clinical usage. Cancer 49 : 2112-2135, 1982

2 Harris NL, Jaffe ES, Stein H, Banks PM, Chan JKC, Cleary ML, Delsol G, De Wolf-Peeters C, Falini B, Gatter KC, Grogan TM, Isaacson PG, Knowles DM, Mason DY, Muller-Hermelink H-K, Pileri SA, Piris MA, Ralfkiaer E, Warnke RA: A revised European-American classification of lymphoid neoplasms : a proposal from the International Lymphoma Study Group. Blood 84 : 1361-1392, 1994

3 Stansfeld AG, Diebold J, Noel H, Kapanci Y, Rilke F, Kelenyi G, Sundstrom C, Lennert K, van Unnik JA, Mioduszewska O, Wright DH : Updated Kiel classification for lymphomas. Lancet. 1 : 292-293, 1988

4 Jaffe ES, Harris NL, Stein H, Vardiman JW eds. : Pathology and Genetics of Tumours of Haematopietic and Lymphoid Tissues. World Health Organization Classification of Tumours, IARC Pres, Lyon, 2001

5 Hercend T, Schmidt RE : Characteristics and uses of natural killer cells. Immunol Today 9: 291-293, 1988

6 Robertson MJ, Ritz J : Biology and clinical relevance of human natural killer cells. Blood 76 : 2421-2438, 1990

7 Farag SS, VanDeusen JB, Feninger TA, Caligiuri MA. Biology and clinical impact of human natural killer cells. Int J Hematol 78: 7- 17, 2003

8 Sanchez MJ, Muench MO, Roncarolo MG, Lanier LL. Phillips $\mathrm{JH}$ : Identification of a common T/natural killer cell progenitor in human fetal thymus. J Exp Med 180 : 569-576, 1994

9 Shibuya A, Nagayoshi K, Nakamura K, Nakauchi H : Lymphokine requirement for the generation of natural killer cells from CD34 ${ }^{+}$hematopoietic progenitor cells. Blood 85 : 3538-3546, 1995

10 Fernandez LA, Pope B, Lee C, Zayed E: Aggressive natural killer cell leukemia in an adult and establishment of an NK cell line. Blood 67 : 925-930, 1986

11 Koizumi S, Seki H, Tachinami T, Taniguchi M, Matsuda A, Taga
K, Nakarai T, Kato E, Taniguchi N, Nakamura H : Malignant clonal expansion of large granular lymphocytes with a Leu-11+, Leu-7- surface phenotype : in vitro responsiveness of malignant cells to recombinant human interleukin 2. Blood 68 : 1065-1073, 1986

12 Imamura N, Kusunoki Y, Kawa-Ha K, Yunuma K, Hara J, Oda K, Abe K, Dohy H, Inada T, Kajihara H, Kuramoto A : Aggressive natural killer cell leukemia/lymphoma : Report of four cases and review of the literature. Br J Haematol 75 : 49-59, 1990

13 Loughran Jr. TP : Clonal diseases of large granular lymphocytes. Blood 82 : 1- 14, 1993

14 Oshimi K, Yamada O, Kaneko T, Nishinarita S, lizuka Y, Urabe A, Inamori T, Asano S, Takahashi S, Hattori M, Naohara T, Ohira Y, Togawa A, Masuda Y, Okubo Y, Furusawa S, Sakamoto S, Omine M, Mori M, Tatsumi E, Mizoguchi H : Laboratory findings and clinical courses of 33 patients with granular lymphocyteproliferative disorders. Leukemia 7: 782-788, 1993

15 Ishii Y, Yamanaka N, Ogawa K, Yoshida Y, Takami T, Matsuura A, Isago H, Kataura A, Kikuchi K : Nasal T-cell lymphoma as a type of so-called "lethal midline granuloma". Cancer 50 : 2336-2344, 1982

16 Stamenkovic I, Toccanier MF, Kapanci Y : Polymorphic reticulosis (lethal midline granuloma) and lymphomatoid granulomatosis : identical or distinct entities ? Virchows Arch A Pathol Anat Histol $390: 81-91,1981$

17 Chan JKC, Ng CS, Ngan KC, Hui PK, Lo ST, Lau WH : Angiocentric T-cell lymphoma of the skin. An aggressive lymphoma distinct from mycosis fungoides. Am J Surg Pathol 12: 861-876, 1988

18 Aviles A, Rodriguez L, Guzman R, Talavera A, Garcia EL, DiazMaqueo JC: Angiocentric T-cell lymphoma of the nose, paranasal sinuses and hard palate. Hematol Oncol 10: 141-147, 1992

19 Suzumiya J, Takeshita M, Kimura M, Kikuchi M, Uchida T, Hisano S, Eura Y, Kozuru M, Nomura Y, Tomita K, Komiyama S, Okumura M : Expression of adult and fetal natural killer cell markers in sinonasal lymphomas. Blood 83 : 2255-2260, 1994

20 Jaffe ES, Chan JKC, Su I-J, Frizzera G, Mori S, Feller AC, Ho FC: Report of the workshop on nasal and related extranodal angiocentric T/natural killer cell lymphomas. Am J Surg Pathol 20: 103-111, 1996

21 Lymphoma Study Group of Japanese Pathologists : The World Health Organization classification of malignant lymphomas in Japan : Incidence of recently recognized entities. Pathol Int 50 : 696- 702, 2000

22 Suzuki R, Suzumiya J, Nakamura S, Aoki S, Notoya A, Ozaki S, Gondo H, Hino N, Mori H, Sugimori H, Kawa K, Oshimi K and the NK-cell Tumor Study Group : Aggressive natural killer-cell leukemia revisited : large granular lymphocyte leukemia of cytotoxic NK cells. Leukemia 18: 763-770, 2004

23 Chan JKC, Wong KF, Jaffe ES, Ralfkiaer E. Aggressive NK-cell leukemia. In : Jaffe ES, Harris NL, Stein H, Vardiman JW, eds. World Health Organization Classification of Tumours ; IARC Pres, Lyon, 198-200, 2001 
24 Kawa-Ha K, Ishihara S, Ninomiya T, Yumura-Yagi K, Hara J, Murayama F, Tawa A, Hirai K : CD3-negative lymphoproliferative disease of granular lymphocytes containing Epstein-Barr viral DNA. J Clin Invest 84 : 51-55, 1989

25 Sheridan W, Winton EF, Chan WC, Gordon DS, Vogler WR, Phillips C, Bongiovanni KF, Waldmann TA : Leukemia of non-T lineage natural killer cells. Blood 72 : 1701-1707, 1988

26 Taniwaki M, Tagawa S, Nishigaki H, Horiike S, Misawa S, Shimazaki C, Maekawa T, Fujii H, Kitani T, Abe T : Chromosomal abnormalities define clonal proliferation in CD3- large granular lymphocyte leukemia. Am J Hematol 33 : 32-38, 1990

27 Kwong YL, Wong KF, Chan LC, Liang RH, Chan JK, Lin CK, Chan TK: Large granular lymphocyte leukemia. A study of nine cases in a Chinese population. Am J Clin Pathol 103 : 76-81, 1995

28 Shimodaira S, Ishida F, Kobayashi H, Mahbub B, Kawa-Ha K, Kitano $\mathrm{K}$ : The detection of clonal proliferation in granular lymphocyte-proliferative disorders of natural killer cell lineage. $\mathrm{Br}$ J Haematol 90 : 578-584, 1995

29 Chan JK, Sin VC, Wong KF, Ng CS, Tsang WY, Chan CH, Cheung MM, Lau WH : Nonnasal lymphoma expressing the natural killer cell marker CD56 : a clinicopathologic study of 49 cases of an uncommon aggressive neoplasm. Blood 89: 4501-4513, 1997

30 Mizuno S, Akashi K, Ohshima K, Iwasaki H, Miyamoto T, Uchida N, Shibuya T, Harada M, Kikuchi M, Niho Y : Interferon-gamma prevents apoptosis in Epstein-Barr virus-infected natural killer cell leukemia in an autocrine fashion. Blood 93 : 3494-3504, 1999

31 Akashi K, Mizuno S : Epstein-Barr virus-infected natural killer cell leukemia. Leuk Lymphoma. 40 : 57-66, 2000

32 Song SY, Kim WS, Ko YH, Kim K, Lee MH, Park K : Aggressive natural killer cell leukemia; clinical features and treatment outcome. Haematologica 87 : 1343-1345, 2002

33 Ishihara S, Ohshima K, Tokura Y, Yabuta R, Imaishi H, Wakiguchi H, Kurashige T, Kishimoto H, Katayama I, Okada S, KawaHa K : Hypersensitivity to mosquito bites conceals clonal lymphoproliferation of Epstein-Barr viral DNA-positive natural killer cells. Jpn J Cancer Res 88 : 82-87, 1997

34 Tokura Y, Ishihara S, Ohshima K, Hidano A, Koide M, Seo N, Takigawa M : Severe mosquito bite hypersensitivity, natural killer cell leukaemia, latent or chronic active Epstein-Barr virus infection and hydroa vacciniforme-like eruption. Br J Dermatol 138 : 905-906, 1998

35 Ishihara S, Yabuta R, Tokura Y, Ohshima K, Tagawa S : Hypersensitivity to mosquito bites is not an allergic disease, but an Epstein-Barr virus-associated lymphoproliferative disease. Int $\mathrm{J}$ Hematol 72: 223-228, 2000

36 Soler J, Bordes R, Ortuno F, Montagud M, Martorell J, Pons C, Nomdedeu J, Lopez-Lopez JJ, Prat J, Rutllant M : Aggressive natural killer cell leukaemia/lymphoma in two patients with lethal midline granuloma. Br J Haematol 86 : 659-662, 1994

37 Pastan I, Gottesman M : Multidrug resistance in human cancer. N Engl J Med 316 : 1388-1393, 1987
38 Yamaguchi M, Kita K, Miwa H, Nishii K, Oka K, Ohno T, Shirakawa S, Fukumoto M: Frequent expression of Pglycoprotein/MDR1 by nasal T-cell lymphoma cells. Cancer 76 : 2351-2356, 1995

39 Drénou B, Lamy T, Amiot L, Fardel O, Caulet-Maugendre S, Sasportes M, Diebold J, Le Prise PY, Fauchet R. CD3- CD56+ non-Hodgkin's lymphomas with an aggressive behavior related to multidrug resistance. Blood 89 : 2966-2974, 1997

40 Egashira M, Kawamata N, Sugimoto K, Kaneko T, Oshimi K : Pglycoprotein expression on normal and abnormally expanded natural killer cells and inhibition of P-glycoprotein function by cyclosporin A and its analogue, PSC833. Blood 93 : 599-606, 1999

41 Chan JKC, Jaffe ES, Ralfkiaer E : Extranodal NK/T-cell lymphoma, nasal type. In : Jaffe ES, Harris NL, Stein H, Vardiman JW, eds. World Health Organization Classification of Tumours. Pathology and genetics of tumours of haematopoietic and lymphoid tissues. IARC Press, Lyon, France, pp. 204-207, 2001

42 Oshimi K : Lymphoproliferative disorders of natural killer cells. Int J Hematol 63 : 279-290, 1996

43 Jaffe ES : Classification of natural killer (NK) cell and NK-like Tcell malignancies. Blood 87 : 1207-1210, 1996

44 Oshimi K: Leukemia and lymphoma of natural killer lineage cells. Int J Hematol 78 : 18-23, 2003

45 The Non-Hodgkin's Lymphoma Classification Project : A clinical evaluation of the International Lymphoma Study Group classification of non-Hodgkin's lymphoma. Blood 89: 3909-3918, 1997

46 Anderson JR, Armitage JO, Weisenburger DD : Epidemiology of the non-Hodgkin's lymphomas : distributions of the major subtypes differ by geographic locations. Non-Hodgkin's Lymphoma Classification Project. Ann Oncol 9: 717-720, 1998

47 Au WY, Ma SY, Chim CS, Jang HK, Lee SS, Kim SH, Ree HJ, Lee JD, Kim SW, Huh JR : Clinicopathologic features and treatment outcome of mature T-cell and natural killer cell lymphomas diagnosed according to the World Health Organization classification scheme : a single center experience of ten years. Ann Oncol 16: 206-214, 2005

48 Ko YH, Kim CW, Park CS, Jang HK, Lee SS, Kim SH, Ree HJ, Lee JD, Kim SW, Huh JR: REAL classification of malignant lymphomas in the Republic of Korea : incidence of recently recognized entities and changes in clinicopathologic features. Hematolymphoreticular Study Group of the Korean Society of Pathologists. Revised European-American lymphoma. Cancer 83 : 806- 812, 1998

49 Chen CY, Yao M, Tang JL, Tsay W, Wang CC, Chou WC, Su IJ, Lee FY, Liu MC, Tien HF : Chromosomal abnormalities of 200 Chinese patients with non-Hodgkin's lymphoma in Taiwan : with special reference to T-cell lymphoma. Ann Oncol 15: 1091-1096, 2004

50 Yamaguchi M, Ohno T, Oka K, Nishii K, Kawakami K, Miwa H, Kita K, Shirakawa S: Discordant reaction of Leu4 and rabbit anti-human CD3 epsilon in sinonasal ' $\mathrm{T}$ '-cell lymphoma. Int $\mathrm{J}$ Hematol 59: 25-30, 1993

51 Chan JKC, Tsang WY, Pau MY : Discordant CD3 expression in 


\section{R. Suzuki}

lymphomas when studied on frozen and paraffin sections. Hum Pathol 26 : 1139- 1143, 1995

52 Emile J-F, Boulland M-L, Haioun C, Kanavaros P, Petrella T, Delfau-Larue MH, Bensussan A, Farcet JP, Gaulard P : CD5CD56+ T-cell receptor silent peripheral T-cell lymphomas are natural killer cell lymphomas. Blood 87 : 1466-1473, 1996

53 Mori N, Yatabe Y, Oka K, Kinoshita T, Kobayashi T, Ono T, Asai $\mathrm{J}$ : Expression of perforin in nasal lymphoma. Additional evidence of its natural killer cell derivation. Am J Pathol 149: 699-705, 1996

54 Felgar RE, Macon WR, Kinney MC, Roberts S, Pasha T, Salhany KE : TIA-1 expression in lymphoid neoplasms. Identification of subsets with cytotoxic T lymphocyte or natural killer cell differentiation. Am J Pathol 150 : 1893-1900, 1997

55 Ohshima K, Suzumiya J, Shimazaki K, Kato A, Tanaka T, Kanda M, Kikuchi M : Nasal T/NK cell lymphomas commonly express perforin and Fas ligand: important mediators of tissue damage. Histopathology $31:$ 444-450, 1997

$56 \mathrm{Ng}$ CS, Lo ST, Chan JK, Chan WC: CD56+ putative natural killer cell lymphomas : production of cytolytic effectors and related proteins mediating tumor cell apoptosis ? Hum Pathol 28 : 1276-1282, 1997

57 Boulland ML, Kanavaros P, Wechsler J, Casiraghi O, Gaulard P : Cytotoxic protein expression in natural killer cell lymphomas and in alpha beta and gamma delta peripheral T-cell lymphomas. J Pathol 183 : 432-439, 1997

58 Yamashita Y, Yatabe Y, Tsuzuki T, Nakayama A, Hasegawa Y, Kojima H, Nagasawa T, Mori N : Perforin and granzyme expression in cytotoxic T-cell lymphomas. Mod Pathol 11: 313-323, 1998

59 Krenacs L, Smyth MJ, Bagdi E, Krenacs T, Kopper L, Rudiger T, Zettl A, Muller-Hermelink HK, Jaffe ES, Raffeld M: The serine protease granzyme $\mathrm{M}$ is preferentially expressed in NK-cell, gamma delta T-cell, and intestinal T-cell lymphomas: evidence of origin from lymphocytes involved in innate immunity. Blood 101 : 3590- 3593, 2003

60 Sato K, Kimura F, Nakamura Y, Murakami H, Yoshida M, Tanaka M, Nagata S, Kanatani Y, Wakimoto N, Nagata N, Motoyoshi K : An aggressive nasal lymphoma accompanied by high levels of soluble Fas ligand. Br J Haematol 94 : 379-382, 1996

61 Kato K, Ohshima K, Ishihara S, Anzai K, Suzumiya J, Kikuchi $\mathrm{M}$ : Elevated serum soluble Fas ligand in natural killer cell proliferative disorders. Br J Haematol 103 : 1164- 1166, 1998

62 Mullauer L, Mosberger I, Chott A : Fas ligand expression in nodal non-Hodgkin's lymphoma. Mod Pathol 11 : 369-375, 1998

63 Haedicke W, Ho FC, Chott A, Moretta L, Rudiger T, Ott G, Muller-Hermelink HK : Expression of CD94/NKG2A and killer immunoglobulin-like receptors in NK cells and a subset of extranodal cytotoxic T-cell lymphomas. Blood 95 : 3628-3630, 2000

64 Hoffmann T, De Libero G, Colonna M, Wodnar-Filipowicz A, Passweg J, Favre G, Gratwohl A, Tichelli A : Natural killer-type receptors for HLA class I antigens are clonally expressed in lymphoproliferative disorders of natural killer and T-cell type. Br J
Haematol 110 : 525-536, 2000

65 Dukers DF, Vermeer MH, Jaspars LH, Sander CA, Flaig MJ, Vos W, Willemze R, Meijer CJ : Expression of killer cell inhibitory receptors is restricted to true NK cell lymphomas and a subset of intestinal enteropathy-type $\mathrm{T}$ cell lymphomas with a cytotoxic phenotype. J Clin Pathol 54 : 224-228, 2001

66 Mori KL, Egashira M, Oshimi K : Differentiation stage of natural killer cell-lineage lymphoproliferative disorders based on phenotypic analysis. Br J Haematol 115 : 225-228, 2001

67 Lin CW, Chen YH, Chuang YC, Liu TY, Hsu SM : CD94 transcripts imply a better prognosis in nasal-type extranodal NK/T-cell lymphoma. Blood 102 : 2623-2631, 2003

68 Harabuchi Y, Yamanaka N, Kataura A, Imai S, Kinoshita T, Mizuno F, Osato T : Epstein-Barr virus in nasal T-cell lymphomas in patients with lethal midline granuloma. Lancet 335 : 128-130, 1990

69 Kanavaros P, Lescs MC, Briere J, Divine M, Galateau F, Joab I, Bosq J, Farcet JP, Reyes F, Gaulard P : Nasal T-cell lymphoma : a clinicopathologic entity associated with peculiar phenotype and with Epstein-Barr virus. Blood 81: 2688-2695, 1993

70 Chan JK, Yip TT, Tsang WY, Ng CS, Lau WH, Poon YF, Wong CC, Ma VW : Detection of Epstein-Barr viral RNA in malignant lymphomas of the upper aerodigestive tract. Am J Surg Pathol 18 : 938-946, 1994

71 Wong KF, Chan JK, Kwong YL: Identification of del(6) (q21q25) as a recurring chromosomal abnormality in putative NK cell lymphoma/leukaemia. Br J Haematol 98 : 922-926, 1997

72 Tien HF, Su IJ, Tang JL, Liu MC, Lee FY, Chen YC, Chuang SM : Clonal chromosomal abnormalities as direct evidence for clonality in nasal T/natural killer cell lymphomas. Br J Haematol 97 : 621-625, 1997

73 Gaidano G, Hauptschein RS, Parsa NZ, Offit K, Rao PH, Lenoir G, Knowles DM, Chaganti RS, Dalla-Favera R: Deletions involving two distinct regions of $6 \mathrm{q}$ in B-cell non-Hodgkin lymphoma. Blood 80: 1781-1787, 1992

74 Merup M, Moreno TC, Heyman M, Ronnberg K, Grander D, Detlofsson R, Rasool O, Liu Y, Soderhall S, Juliusson G, Gahrton G, Einhorn S : 6q deletions in acute lymphoblastic leukemia and non-Hodgkin's lymphomas. Blood 91 : 3397-3400, 1998

75 Liang R, Todd D, Chan TK, Chiu E, Lie A, Kwong YL, Choy D, Ho FC: Treatment outcome and prognostic factors for primary nasal lymphoma. J Clin Oncol 13: 666-670, 1995

76 Kwong YL, Chan ACL, Liang R, Chiang AK, Chim CS, Chan TK, Todd D, Ho FC : CD56+ NK lymphomas : clinicopathological features and prognosis. Br J Haematol 97 : 821-829, 1997

77 Logsdon MD, Ha CS, Kavadi VS, Cabanillas F, Hess MA, Cox JD : Lymphoma of the nasal cavity and paranasal sinuses : improved outcome and altered prognostic factors with combined modality therapy. Cancer 80 : 477-488, 1997

78 Cheung MMC, Chan JK, Lau WH, Foo W, Chan PT, Ng CS, Ngan RK : Primary non-Hodgkin's lymphoma of the nose and nasopharynx: clinical features, tumor immunophenotype, and treatment outcome in 113 patients. J Clin Oncol 16: 70- 77, 1998 
79 Ko YH, Ree HJ, Kim WS, Choi WH, Moon WS, Kim SW : Clinicopathologic and genotypic study of extranodal nasal-type natural killer/T-cell lymphoma and natural killer precursor lymphoma among Koreans. Cancer 89: 2106-2116, 2000

80 Li CC, Tien HF, Tang JL, Yao M, Chen YC, Su IJ, Hsu SM, Hong RL: Treatment outcome and pattern of failure in 77 patients with sinonasal natural killer/T-cell or T-cell lymphoma. Cancer 100 : 366-375, 2004

81 Chim CS, Ma SY, Au WY, Choy C, Lie AK, Liang R, Yau CC, Kwong YL: Primary nasal natural killer cell lymphoma: longterm treatment outcome and relationship with the international prognostic index. Blood 103 : 216-221, 2004

82 You JY, Chi KH, Yang MH, Chen CC, Ho CH, Chau WK, Hsu HC, Gau JP, Tzeng CH, Liu JH, Chen PM, Chiou TJ : Radiation therapy versus chemotherapy as initial treatment for localized nasal natural killer (NK)/T-cell lymphoma : a single institute survey in Taiwan. Ann Oncol 15:618-625, 2004

83 Kern WF, Spier CM, Hannneman EH, Miller TP, MatznerM, Grogan TM : Neural cell adhesion molecule-positive peripheral T-cell lymphoma : a rare variant with a propensity for unusual sites of involvement. Blood 79: 2432-2437, 1992

84 Wong KF, Chan JKC, Ng CS, Lee KC, Tsang WYW, Cheung MMC : CD56 (NKH1)-positive hematolymphoid malignancies : an aggressive neoplasm featuring frequent cutaneous/mucosal involvement, cytoplasmic azurophilic granules, and angiocentricity. Hum Pathol 23 : 798- 804, 1992

85 Rodriguez J, Romaguera JE, Manning J, Ordonez N, Ha C, Ravandi F, Cabanillas F : Nasal-type T/NK lymphomas: a clinicopathologic study of 13 cases. Leuk Lymphoma 39: 139-144, 2000

86 Mraz-Gernhard S, Natkunam Y, Hoppe RT, LeBoit P, Kohler S, Kim YH : Natural killer/natural killer-like T-cell lymphoma, CD56+, presenting in the skin : an increasingly recognized entity with an aggressive course. J Clin Oncol 19: 2179-2188, 2001

87 Santucci M, Pimpinelli N, Massi D, Kadin ME, Meijer CJ, MullerHermelink HK, Paulli M, Wechsler J, Willemze R, Audring H, Bernengo MG, Cerroni L, Chimenti S, Chott A, Diaz-Perez JL, Dippel E, Duncan LM, Feller AC, Geerts ML, Hallermann C, Kempf W, Russell-Jones R, Sander C, Berti E for the EORTC Cutaneous Lymphoma Task Force: Cytotoxic/natural killer cell cutaneous lymphomas. Report of EORTC Cutaneous Lymphoma Task Force Workshop. Cancer 97 : 610-627, 2003

88 Massone C, Chott A, Metze D, Kerl K, Citarella L, Vale E, Kerl $\mathrm{H}$, Cerroni L : Subcutaneous, blastic natural killer (NK), NK/Tcell, and other cytotoxic lymphomas of the skin : a morphologic, immunophenotypic, and molecular study of 50 patients. Am J Surg Pathol 28: 719-735, 2004

89 Bekkenk MW, Jansen PM, Meijer CJ, Willemze R: CD56+ hematological neoplasms presenting in the skin : a retrospective analysis of 23 new cases and 130 cases from the literature. Ann Oncol 15: 1097-1108, 2004

90 Ko YH, Cho EY, Kim JE, Lee SS, Huh JR, Chang HK, Yang WI, Kim CW, Kim SW, Ree HJ : NK and NK-like T-cell lymphoma in extranasal sites: a comparative clinicopathological study according to site and EBV status. Histopathology $44: 480-489$, 2004

91 Chim CS, Ma ES, Loong F, Kwong YL: Diagnostic cues for natural killer cell lymphoma: primary nodal presentation and the role of in situ hybridisation for Epstein-Barr virus encoded early small RNA in detecting occult bone marrow involvement. J Clin Pathol 58: 443-445, 2005

$92 \mathrm{Yu} \mathrm{KH,} \mathrm{Yu} \mathrm{SC,} \mathrm{Teo} \mathrm{PM,} \mathrm{Chan} \mathrm{AT,} \mathrm{Yeo} \mathrm{W,} \mathrm{Chow} \mathrm{J} \mathrm{:} \mathrm{Nasal}$ lymphoma: results of local radiotherapy with or without chemotherapy. Head Neck 19: 251-259, 1997

93 Shikama N, Izuno I, Oguchi M, Gomi K, Sone S, Takei K, Sasaki $\mathrm{S}$, Wako T, Itou N, Ishii K : Clinical stage IE primary lymphoma of the nasal cavity : radiation therapy and chemotherapy. Radiology 204 : 467-470, 1997

94 Li YX, Coucke PA, Li JY, Gu DZ, Liu XF, Zhou LQ, Mirimanoff RO, Yu ZH, Huang YR : Primary non-Hodgkin's lymphoma of the nasal cavity: prognostic significance of paranasal extension and the role of radiotherapy and chemotherapy. Cancer 83 : 449-456, 1998

95 Kim GE, Cho JH, Yang WI, Chung EJ, Suh CO, Park KR, Hong WP, Park IY, Hahn JS, Roh JK, Kim BS : Angiocentric lymphoma of the head and neck : patterns of systemic failure after radiation treatment. J Clin Oncol 18: 54- 63, 2000

96 Aviles A, Diaz NR, Neri N, Cleto S, Talavera A : Angiocentric nasal T/natural killer cell lymphoma: a single centre study of prognostic factors in 108 patients. Clin Lab Haematol 22: 215-220, 2000

97 Kim WS, Song SY, Ahn YC, Ko YH, Baek CH, Kim DY, Yoon SS, Lee HG, Kang WK, Lee HJ, Park CH, Park K : CHOP followed by involved field radiation : is it optimal for localized nasal natural killer/T-cell lymphoma? Ann Oncol 12: 349-352, 2001

98 Ribrag V, Ell Hajj M, Janot F, Girinsky T, Domenge C, Schwaab G, Fenaux P, Bosq J : Early locoregional high-dose radiotherapy is associated with long-term disease control in localized primary angiocentric lymphoma of the nose and nasopharynx. Leukemia 15 : 1123-1126, 2001

99 Shikama N, Ikeda H, Nakamura S, Oguchi M, Isobe K, Hirota S, Hasegawa M, Nakamura K, Sasai K, Hayabuchi N : Localized aggressive non-Hodgkin's lymphoma of the nasal cavity : a survey by the Japan Lymphoma Radiation Therapy Group. Int J Radiat Oncol Biol Phys 51 : 1228-1233, 2001

100 Yamaguchi M, Ogawa S, Nomoto Y, Oka K, Taniguchi M, Nakase K, Kobayashi T, Shiku H : Treatment outcome of nasal NK-cell lymphoma: A report of 12 consecutively-diagnosed cases and a review of the literature. J Clin Exp Hematopathol 41 : 93-99, 2001

101 Cheung MMC, Chan JKC, Lau W-H, Ngan RK, Foo WW : Early stage nasal NK/T-cell lymphoma : clinical outcome, prognostic factor, and the effect of treatment modality. Int J Radiat Oncol Biol Phys 54 : 182-190, 2002

102 Nakamura S, Suchi T, Koshikawa T, Kitoh K, Koike K, Komatsu H, Iida S, Kagami Y, Ogura M, Katoh E, Kurita S, Suzuki H, 
Kobayashi Y, Yamabe H, Hirabayashi N, Ueda R, Takahashi T : Clinicopathologic study of CD56 (NCAM)-positive angiocentric lymphoma occurring in sites other than the upper and lower respiratory tract. Am J Surg Pathol 19: 284-296, 1995

103 DiGiuseppe JA, Louie DC, Williams JE, Miller DT, Griffin CA, Mann RB, Borowitz MJ : Blastic natural killer cell leukemia/ lymphoma: A clinicopathologic study. Am J Surg Pathol 21 : 1223-1230, 1997

104 Suzuki R, Nakamura S : Malignancies of natural killer (NK) cell precursor : myeloid/NK cell precursor acute leukemia and blastic NK cell lymphoma/leukemia. Leuk Res 23 : 615-624, 1999

105 Chan JKC, Jaffe ES, Ralfkiaer E. Blastic NK-cell lymphoma. In : Jaffe ES, Harris NL, Stein H, Vardiman JW (eds). World Health Organization Classification of Tumours: Pathology and Genetics of Tumours of Haematopoietic and Lymphoid Tissues. Lyon: IARC Press, 2001, pp 214-215.

106 Falcao RP, Garcia AB, Marques MG, Simoes BP, Fonseca BA, Rodrigues ML Foss NT: Blastic CD4 NK cell leukemia/ lymphoma: a distinct clinical entity. Leuk Res 26 : 803-807, 2002

107 Khoury JD, Medeiros LJ, Manning JT, Sulak LE, Bueso-Ramos C, Jones D. $\mathrm{CD}^{+} 6^{+} \mathrm{TdT}^{+}$blastic natural killer cell tumor of the skin : a primitive systemic malignancy related to myelomonocytic leukemia. Cancer 94 : 2401-2408, 2002

108 Reimer P, Rudiger T, Kraemer D, Kunzmann V, Weissinger F, Zettl A, Muller-Hermelink HK, Wilhelm M: What is CD4+ CD56+ malignancy and how should it be treated ? Bone Marrow Transplant 32: 637-646, 2003

109 Karube K, Ohshima K, Tsuchiya T, Yamaguchi T, Suefuji H, Suzumiya J, Harada M, Kikuchi M : Non-B, non-T neoplasms with lymphoblast morphology: further clarification and classification. Am J Surg Pathol 27 : 1366-1374, 2003

110 Suzuki R, Nakamura S, Suzumiya J, Ichimura K, Ichikawa M, Ogata K, Kura Y, Aikawa K, Teshima H, Sako M, Kojima H, Nishio M, Yoshino T, Sugimori H, Kawa K, Oshimi K for the NK-cell Tumor Study Group : Blastic natural killer cell lymphoma/leukemia (CD56-positive blastic tumor) : prognostication and categorization according to anatomic sites of involvement. Cancer 104 : 1022-1031, 2005

111 Pirruccello SJ, Bicak MS, Gordon BG, Gajl-Peczalska K, Gnarra DJ, Coccia PF : Acute lymphoblastic leukemia of NK-cell lineage : Response to IL-2. Leuk Res 13, 735-743, 1989

112 Ichikawa M, Kawai H, Komiyama A, Tsudo M, Miyasaka M, Kinoshita A, Nakazawa S : Functional p75 interleukin-2 receptor expression on the fresh blast cells in childhood acute lymphoblastic leukemia with natural killer cell properties. Am J Hematol 36: 259-264, 1991

113 Brody JP, Allen S, Schulman P, Sun T, Chan WC, Friedman HD, Teichberg S, Koduru P, Cone RW, Loughran Jr TP : Acute agranular CD4-positive natural killer cell leukemia. Cancer 75 : 2474-2483, 1994

114 Gardiner CM, Reen DJ, O'Meara A : Recognition of unusual presentation of natural killer cell leukemia. Am J Hematol 50 :
133-139, 1995

115 Nakamura F, Tatsumi E, Kawano S, Tani A, Kumagai S, Nishikori M, Nagai T: Acute lymphoblastic leukemia/lymphoblastic lymphoma of natural killer (NK) lineage : quest for another NKlineage neoplasm. Blood 89: 4665-4666, 1997

116 Shinoda K, Muraki T, Yano M, Yamada T, Takao A : Infant leukemia suggestive of natural killer cell precursor origin followed an unusual clinical course. Acta Haematol 104 : 202-206, 2000

117 Chaperot L, Bendriss N, Manches O, Gressin R, Maynadie M, Trimoreau F, Orfeuvre H, Corront B, Feuillard J, Sotto JJ, Bensa JC, Briere F, Plumas J, Jacob MC : Identification of a leukemic counterpart of the plasmacytoid dendritic cells. Blood 97 : 3210-3217, 2001

118 Feuillard J, Jacob MC, Valensi F, Maynadie M, Gressin R, Chaperot L, Arnoulet C, Brignole-Baudouin F, Drenou B, Duchayne E, Falkenrodt A, Garand R, Homolle E, Husson B, Kuhlein E, Le Calvez G, Sainty D, Sotto MF, Trimoreau F, Bene $\mathrm{MC}$ : Clinical and biologic features of CD4+ CD56+ malignancies. Blood 99 : 1556-1563, 2002

119 Petrella T, Comeau MR, Maynadie M, Couillault G, De Muret A, Maliszewski CR, Dalac S, Durlach A, Galibert L: Agranular CD4+ CD56+ hematodermic neoplasm' (blastic NK-cell lymphoma) originates from a population of $\mathrm{CD} 56+$ precursor cells related to plasmacytoid monocytes. Am J Surg Pathol 26 : 852- 862,2002

120 O'Doherty U, Steinman RM, Peng M, Cameron PU, Gezelter S, Kopeloff I, Swiggard WJ, Pope M, Bhardwaj N : Dendritic cells freshly isolated from human blood express CD4 and mature into typical immunostimulatory dendritic cells after culture in monocyte-conditioned medium. J Exp Med 178: 1067-1076, 1993

121 Vandenabeele S, Hochrein H, Mavaddat N, Winkel K, Shortman $\mathrm{K}$ : Human thymus contains 2 distinct dendritic cell populations. Blood 97 : 1733-1741, 2001

122 MacDonald KPA, Munster DJ, Clark GJ, Dzionek A, Schmitz J, Hart DNJ : Characterization of human blood dendritic cell subsets. Blood 100 : 4512-4520, 2002

123 Comeau MR, Van der Vuurst de Vries A-R, Maliszewski CR, Galibert L : CD123 bright plasmacytoid predendritic cells : progenitors undergoing cell fate conversion? J Immunol 169 : 75-83, 2002

124 Sato N, Caux C, Kitamura T, Watanabe Y, Arai K, Banchereau J, Miyajima A : Expression and factor-dependent modulation of the interleukin-3 receptor subunits on human hematopoietic cells. Blood 82 : 752-761, 1993

125 Miyajima A, Mui AL, Ogorochi T, Sakamaki K : Receptors for granulocyte-macrophage colony-stimulating factor, interleukin3, and interleukin-5. Blood 82 : 1960-1974, 1993

126 Momoi A, Toba K, Kawai K, Tsuchiyama J, Suzuki N, Yano T, Uesugi Y, Takahashi M, Aizawa Y: Cutaneous lymphoblastic lymphoma of putative plasmacytoid dendritic cell-precursor origin : two cases. Leuk Res 26: 693-698, 2002 
127 Petrella T, Meijer CJ, Dalac S, Willemze R, Maynadie M, Machet L, Casasnovas O, Vergier B, Teitell MA: TCL1 and CLA expression in agranular CD4/CD56 hematodermic neoplasms (blastic NK-cell lymphomas) and leukemia cutis. Am J Clin Pathol 122 : 307-313, 2004

128 Suzuki R, Yamamoto K, Seto M, Kagami Y, Ogura M, Yatabe Y, Suchi T, Kodera Y, Morishima Y, Takahashi T, Saito H, Ueda $\mathrm{R}$, Nakamura $\mathrm{S}: \mathrm{CD}^{+}$and $\mathrm{CD}^{+} 6^{+}$myeloid/natural killer cell precursor acute leukemia: A distinct hematolymphoid disease entity. Blood 90 : 2417-2428, 1997

129 Bennett JM, Catovsky D, Daniel M-T, Flandrin G, Galton DAG, Gralnick HR, Sultan C : Proposal for the recognition of minimally differentiated acute myeloid leukemia (AML-M0). Br J Haematol 78: 325-329, 1991

130 Béné M-C, Bernier M, Casasnovas RO, Castoldi G, Doekharan D, van der Holt B, Knapp W, Lemez P, Ludwig WD, Matutes E, Orfao A, Schoch C, Sperling C, van't Veer MB : Acute myeloid leukaemia M0: haematological, immunophenotypic and cytogenetic characteristics and their prognostic significance : an analysis in 241 patients. Br J Haematol 113: 737- 745, 2001

131 Scott AA, Head DR, Kopecky KJ, Appelbaum FR, Theil KS, Grever MR, Chen IM, Whittaker MH, Griffith BB, Licht JD, Waxman S, Whalen MM, Bankhurst AD, Richter LC, Grogan TM, Willman CL : HLA-DR-, CD33+, CD56+, CD16- myeloid/ natural killer cell acute leukemia: a previously unrecognized form of acute leukemia potentially misdiagnosed as FrenchAmerican-British acute myeloid leukemia-M3. Blood 84 : 244-253, 1994

132 Suzuki R, Murata M, Kami M, Ohtake S, Asou N, Kodera Y, Tomonaga M, Masaki Y, Kusumoto S, Takeuchi J, Matsuda S, Hirai H, Yorimitsu S, Hamajima N, Seto M, Shimoyama M, Ohno R, Morishima Y, Nakamura S : Prognostic significance of CD7+ CD56+ phenotype and chromosome 5 abnormalities for acute myeloid leukemia M0. Int J Hematol 77 : 482-489, 2003

133 Oshimi K, Kawa K, Nakamura S, Suzuki R, Suzumiya J, Yamaguchi M, Kameoka J, Tagawa S, Imamura N, Ohshima K, Kojya S, Iwatsuki K, Tokura Y, Sato E, Sugimori H : NK-cell Tumor Study Group. NK-cell neoplasms in Japan. Hematology J 10 : 237-245, 2005

134 Kuerbitz SJ, Civin CI, Krischer JP, Ravindranath Y, Steuber CP, Weinsein HJ, Winick N, Ragab AH, Gresik MV, Crist WM : Expression of myeloid-associated and lymphoid-associated cellsurface antigens in acute myeloid leukemia of childhood: A pediatric oncology group study. J Clin Oncol 10 : 1419-1429, 1992

135 Vidriales MB, Orfao A, Gonzalez M, Hernandez JM, LopezBerges MC, Garcia MA, Canizo MC, Caballero MD, Macedo A, Landolfi $\mathrm{C}$ : Expression of NK and lymphoid-associated antigens in blast cells of acute myeloblastic leukemia. Leukemia 7 : 2026-2029, 1993

136 Seymour JF, Pierce SA, Kantarjian HM, Keating MI, Estey EH : Investigation of karyotypic, morphologic and clinical features in patients with acute myeloid leukemia blast cells expressing the neural cell adhesion molecule (CD56). Leukemia 8: 823-826, 1994

137 Raspadori D, Damiani D, Lenoci M, Rondelli D, Testoni N, Nardi G, Sestigiani C, Mariotti C, Birtolo S, Tozzi M, Lauria F : CD56 antigenic expression in acute myeloid leukemia identifies patients with poor clinical prognosis. Leukemia 15 : 1161-1164, 2001

138 Raspadori D, Damiani D, Michieli M, Stocchi R, Gentili S, Gozzetti A, Masolini P, Michelutti A, Geromin A, Fanin R, Lauria F : CD56 and PGP expression in acute myeloid leukemia: impact on clinical outcome. Haematologica 87 : 1135-1140, 2002

139 Chang H, Salma F, Yi QL, Patterson B, Brien B, Minden MD : Prognostic relevance of immunophenotyping in 379 patients with acute myeloid leukemia. Leuk Res 28: 43-48, 2004

140 Baer MR, Stewart CC, Lawrence D, Arthur DC, Byrd JC, Davey FR, Schiffer CA, Bloomfield CD : Expression of the neural cell adhesion molecule CD56 is associated with short remission duration and survival in acute myeloid leukemia with $\mathrm{t}(8 ; 21)(\mathrm{q} 22$; q22). Blood 90 : 1643-1648, 1997

141 Murray CK, Estey E, Paietta E, Howard RS, Edenfield WJ, Pierce S, Mann KP, Bolan C, Byrd JC: CD56 expression in acute promyelocytic leukemia: a possible indicator of poor treatment outcome? J Clin Oncol 17 : 293-297, 1999

142 Ferrara F, Morabito F, Martino B, Specchia G, Liso V, Nobile F, Boccuni P, Di Noto R, Pane F, Annunziata M, Schiavone EM, De Simone M, Guglielmi C, Del Vecchio L, Lo Coco F : CD56 expression is an indicator of poor clinical outcome in patients with acute promyelocytic leukemia treated with simultaneous alltrans-retinoic acid and chemotherapy. J Clin Oncol 18 : 1295-1300, 2000

143 Di Bona E, Sartori R, Zambello R, Guercini N, Madeo D, Rodeghiero F : Prognostic significance of CD56 antigen expression in acute myeloid leukemia. Haematologica 87 : 250-256, 2002

144 Ito S, Ishida Y, Oyake T, Satoh M, Aoki Y, Kowata S, Uchiyama T, Enomoto S, Sugawara T, Numaoka H, Suzuki K, Murai K : Clinical and biological significance of CD56 antigen expression in acute promyelocytic leukemia. Leuk Lymphoma 45 : 1783-1789, 2004

145 Thomas X, Vila L, Campos L, Sabido O, Archimbaud E: Expression of N-CAM (CD56) on acute leukemia cells : relationship with disease characteristics and outcome. Leuk Lymphoma 19: 295-300, 1995

146 Paietta E, Neuberg D, Richards S, Bennett JM, Han L, Racevskis J, Dewald G, Rowe JM, Wiernik PH : Eastern Cooperative Oncology Group. Rare adult acute lymphocytic leukemia with CD56 expression in the ECOG experience shows unexpected phenotypic and genotypic heterogeneity. Am J Hematol 66 : 189- 196, 2001

147 Pombo-de-Oliveira MS, Campos MM, Bossa YE, Alencar DM, Curvello C, Agudelo DP, Mendonca N, Pereira E, Macedo-Silva ML : Acute leukemia with natural killer cells antigens in Brazi- 


\section{R. Suzuki}

lian children. Leuk Lymphoma 45 : 739- 743, 2004

148 Krenacs L, Wellmann A, Sorbara L, Himmelmann AW, Bagdi E, Jaffe ES, Raffeld M : Cytotoxic cell antigen expression in anaplastic large cell lymphomas of T- and null-cell type and Hodgkin's disease : evidence for distinct cellular origin. Blood 89 : 980-989, 1997

149 Arnulf B, Copie-Bergman C, Delfau-Larue MH, Lavergne-Slove A, Bosq J, Wechsler J, Wassef M, Matuchansky C, Epardeau B, Stern M, Bagot M, Reyes F, Gaulard P : Nonhepatosplenic gammadelta T-cell lymphoma: a subset of cytotoxic lymphomas with mucosal or skin localization. Blood 91 : 1723-1731, 1998

150 Chott A, Haedicke W, Mosberger I, Fodinger M, Winkler K, Mannhalter C, Muller-Hermelink HK : Most CD56+ intestinal lymphomas are CD8+CD5-T-cell lymphomas of monomorphic small to medium size histology. Am J Pathol 153 : 1483-1490, 1998

151 Felgar RE, Salhany KE, Macon WR, Pietra GG, Kinney MC : The expression of TIA-1+ cytolytic-type granules and other cytolytic lymphocyte-associated markers in CD30+ anaplastic large cell lymphomas (ALCL) : correlation with morphology, immunophenotype, ultrastructure, and clinical features. Hum Pathol 30 : 228-236, 1999

152 Suzuki R, Kagami Y, Takeuchi K, Kami M, Okamoto M, Ichinohasama R, Mori N, Kojima M, Yoshino T, Yamabe H, Shiota M, Mori S, Ogura M, Hamajima N, Seto M, Suchi T, Morishima Y, Nakamura S. Prognostic significance of CD56 expression for ALK-positive and ALK-negative anaplastic large cell lymphoma of T/null cell phenotype. Blood 96: 2993-3000, 2000

153 Asano N, Suzuki R, Kagami Y, Ishida F, Kitamura K, Fukutani H, Morishima Y, Takeuchi K, Nakamura S : Clinicopathologic and prognostic significance of cytotoxic molecule expression in nodal peripheral T-cell lymphoma, unspecified. Am J Surg Pathol 29: 1284-1293, 2005

154 Macon WR, Williams ME, Greer JP, Hammer RD, Glick AD, Collins RD, Cousar JB : Natural killer-like T-cell lymphomas : aggressive lymphomas of T-large granular lymphocytes. Blood 87 : 1474-1483, 1996

155 Mraz-Gemhard S, Natkunam Y, Hoppe RT, LeBoit P, Kohler S, Kim YH : Natural killer/natural killer-like T-cell lymphoma, CD56+, presenting in the skin : an increasingly recognized entity with an aggressive course. J Clin Oncol 19: 2179-2188, 2001

156 Ralfkiaer E, Muller-Hermelink HK, Jaffe ES : Peripheral T-cell lymphoma, unspecified. In World Health Organization classification of tumors. Pathology and genetics of tumours of haematopoietic and lymphoid tissues (edited by Jaffe ES, Harris NL, Stein H, Vardiman JW), IARC Press, Lyon, France, p. 227-229, 2001

157 Ohno T, Yamaguchi M, Oka K, Miwa H, Kita K, Shirakawa S : Frequent expression of CD3 epsilon in CD3 (Leu 4)-negative nasal T-cell lymphomas. Leukemia 9: 44- 52, 1995.

158 Weidmann E : Hepatosplenic T-cell lymphoma. A review on 45 cases since the first report describing the disease as a distinct lymphoma entity in 1990. Leukemia 14: 991-997, 2000
159 Macon WR, Levy NB, Kurtin PJ, Salhany KE, Elkhalifa MY, Casey TT, Craig FE, Vnencak-Jones CL, Gulley ML, Park JP, Cousar JB : Hepatosplenic $\alpha \beta$ T-cell lymphomas : a report of 14 cases and comparison with hepatosplenic $\gamma \delta$ T-cell lymphomas. Am J Surg Pathol 25: 285-296, 2001

160 Belhadj K, Reyes F, Farcet JP, Tilly H, Bastard C, Angonin R, Deconinck E, Charlotte F, Leblond V, Labouyrie E, Lederlin P, Emile JF, Delmas-Marsalet B, Arnulf B, Zafrani ES, Gaulard P : Hepatosplenic gammadelta T-cell lymphoma is a rare clinicopathologic entity with poor outcome : report on a series of 21 patients. Blood 102: 4261-4269, 2003

161 Gale J, Simmonds PD, Mead GM, Sweetenham JW, Wright DH : Enteropathy-type intestinal T-cell lymphoma: clinical features and treatment of 31 patients in a single center. J Clin Oncol 18 : 795- 803, 2000

162 Garin-Chesa P, Fellinger EJ, Huvos AG, Beresford HR, Melamed MR, Triche TJ, Rettig WJ : Immunohistochemical analysis of neural cell adhesion molecules. Differential expression in small round cell tumors of childhood and adolescence. Am J Pathol 139 : 275-286, 1991

163 Mechtersheimer G, Staudter M, Moller P : Expression of the natural killer cell-associated antigens CD56 and CD57 in human neural and striated muscle cells and in their tumors. Cancer Res 51: 1300-1307, 1991

164 Roth J, Blaha I, Bitter-Suermann D, Heitz PU : Blastemal cells of nephroblastomatosis complex share an onco-developmental antigen with embryonic kidney and Wilms' tumor. An immunohistochemical study on polysialic acid distribution. Am J Pathol 133: 596-608, 1988

165 Komminoth P, Roth J, Lackie PM, Bitter-Suermann D, Heitz PU : Polysialic acid of the neural cell adhesion molecule distinguishes small cell lung carcinoma from carcinoids. Am J Pathol 139 : 297-304, 1991

166 Beiske K, Myklebust AT, Aamdal S, Langholm R, Jakobsen E, Fodstad O : Detection of bone marrow metastases in small cell lung cancer patients. Comparison of immunologic and morphologic methods. Am J Pathol 141: 531-538, 1992

167 Ohshima K, Haraoka S, Ishihara S, Ohgami A, Yoshioka S, Suzumiya J, Kikuchi M : Analysis of chromosome 6q deletion in EBV-associated NK cell leukemia/lymphoma. Leuk Lymphoma $43: 293-300,2002$

168 Sun HS, Su I-J, Lin Y-C, Chen J-S, Fang S-Y : A $2.6 \mathrm{Mb}$ interval on chromosome 6q25.2-q25.3 is commonly deleted in human nasal natural killer/T-cell lymphoma. Br J Haematol 122 : 590-599, 2003

169 Yoon J, Ko YH : Deletion mapping of the long arm of chromosome 6 in peripheral T and NK cell lymphomas. Leuk Lymphoma 44 : 2077-2082, 2003

170 Sakajiri S, Kawamata N, Egashira M, Mori K, Oshimi K. Molecular analysis of tumor suppressor genes, Rb, p53, p16INK4A, p15INK4B and p14ARF in natural killer cell neoplasms. Jpn J Cancer Res 92 : 1048-1056, 2001

171 Sugimoto KJ, Kawamata N, Sakajiri S, Oshimi K. Molecular 
analysis of oncogenes, ras family genes (N-ras, K-ras, H-ras), myc family genes (c-myc, N-myc) and mdm2 in natural killer cell neoplasms. Jpn J Cancer Res 93 : 1270-1277, 2002

172 Takakuwa T, Dong Z, Nakatsuka S, Kojya S, Harabuchi Y, Yang WI, Nagata S, Aozasa K: Frequent mutations of Fas gene in nasal NK/T cell lymphoma. Oncogene 21: 4702-4705, 2002

173 Shen L, Liang AC, Lu L, Au WY, Kwong YL, Liang RH, Srivastava $G$ : Frequent deletion of Fas gene sequences encoding death and transmembrane domains in nasal natural killer/T-cell lymphoma. Am J Pathol 161: 2123-2131, 2002

174 Siu LL, Chan JK, Wong KF, Kwong YL: Specific patterns of gene methylation in natural killer cell lymphomas : p73 is consistently involved. Am J Pathol 160 : 59-66, 2002

175 Oka T, Ouchida M, Koyama M, Ogama Y, Takada S, Nakatani Y, Tanaka T, Yoshino T, Hayashi K, Ohara N, Kondo E, Takahashi K, Tsuchiyama J, Tanimoto M, Shimizu K, Akagi T: Gene silencing of the tyrosine phosphatase SHP1 gene by aberrant methylation in leukemias/lymphomas. Cancer Res 62 : 6390-6394, 2002

176 Siu LL, Chan JK, Wong KF, Choy C, Kwong YL: Aberrant promoter $\mathrm{CpG}$ methylation as a molecular marker for disease monitoring in natural killer cell lymphomas. Br J Haematol 122 : 70- 77,2003

177 Takahara M, Kishibe K, Bandoh N, Nonaka S, Harabuchi Y : P53, N- and K-Ras, and beta-catenin gene mutations and prognostic factors in nasal NK/T-cell lymphoma from Hokkaido, Japan. Hum Pathol 35 : 86- 95, 2004

178 Hoshida Y, Hongyo T, Jia X, He Y, Hasui K, Dong Z, Luo WJ, Ham MF, Nomura T, Aozasa K : Analysis of p53, K-ras, c-kit, and beta-catenin gene mutations in sinonasal NK/T cell lymphoma in northeast district of China. Cancer Sci 94 : 297-301, 2003

179 Hongyo T, Hoshida Y, Nakatsuka S, Syaifudin M, Kojya S, Yang WI, Min YH, Chan H, Kim CH, Harabuchi Y, Himi T, Inuyama M, Aozasa K, Nomura T : p53, K-ras, c-kit and betacatenin gene mutations in sinonasal NK/T-cell lymphoma in Korea and Japan. Oncol Report 13: 265-271, 2005

180 Kawamata N, Inagaki N, Mizumura S, Sugimoto KJ, Sakajiri S, Ohyanagi-Hara M, Oshimi K: Methylation status analysis of cell cycle regulatory genes (p16INK4A, p15INK4B, p21Waf1/ Cip1, p27Kip1 and p73) in natural killer cell disorders. Eur J Haematol 74 : 424- 429, 2005

181 Quintanilla-Martinez L, Kremer M, Keller G, Nathrath M, Gamboa-Dominguez A, Meneses A, Luna-Contreras L, Cabras A, Hoefler H, Mohar A, Fend F : p53 Mutations in nasal natural killer/T-cell lymphoma from Mexico : association with large cell morphology and advanced disease. Am J Pathol 159: 2095-2105, 2001

182 Hongyo T, Li T, Syaifudin M, Baskar R, Ikeda H, Kanakura Y, Aozasa K, Nomura $\mathrm{T}$ : Specific c-kit mutations in sinonasal natural killer/T-cell lymphoma in China and Japan. Cancer Res $60: 2345-2347,2000$

183 Siu LL, Wong KF, Chan JK, Kwong YL : Comparative genomic hybridization analysis of natural killer cell lymphoma/leukemia.
Recognition of consistent patterns of genetic alterations. Am J Pathol 155: 1419-1425, 1999

184 Siu LL, Chan V, Chan JK, Wong KF, Liang R, Kwong YL : Consistent patterns of allelic loss in natural killer cell lymphoma. Am J Pathol 157: 1803-1809, 2000

185 Oka T, Yoshino T, Hayashi K, Ohara N, Nakanishi T, Yamaai Y, Hiraki A, Sogawa CA, Kondo E, Teramoto N, Takahashi K, Tsuchiyama J, Akagi T: Reduction of hematopoietic cellspecific tyrosine phosphatase SHP-1 gene expression in natural killer cell lymphoma and various types of lymphomas/ leukemias: combination analysis with cDNA expression array and tissue microarray. Am J Pathol 159: 1495-1505, 2001

186 Ko YH, Choi KE, Han JH, Kim JM, Ree HJ : Comparative genomic hybridization study of nasal-type NK/T-cell lymphoma. Cytometry 46: 85-91, 2001.

187 Nakashima Y, Tagawa H, Suzuki R, Karnan S, Karube K, Ohshima K, Muta K, Nawata H, Morishima Y, Nakamura S, Seto M : Genome-wide array-based comparative genomic hybridization of natural killer cell lymphoma/leukemia: Different genomic alteration patterns of aggressive NK-cell leukemia and extranodal NK/T-cell lymphoma, nasal type. Genes Chromosomes Cancer $44: 247-255,2005$

188 Quintanilla-Martinez L, Jaffe ES : Aggressive NK cell lymphomas : insights into the spectrum of NK cell derived malignancies. Histopathology 37 : 372-374, 2000

189 Hart DNJ, Baker BW, Inglis MJ, Nimmo JC, Starling GC, Deacon E, Rowe M, Beard MEJ : Epstein-Barr viral DNA in acute large granular lymphocyte (natural killer) leukemic cells. Blood 79 : 2116-2123, 1992

190 Kawa K : Epstein-Barr virus-associated diseases in humans. Int J Hematol 71: 108-117, 2000

191 Chiang AK, Tao Q, Srivastava G, Ho FC: Nasal NK- and Tcell lymphomas share the same type of Epstein-Barr virus latency as nasopharyngeal carcinoma and Hodgkin's disease. Int J Cancer 68 : 285-290, 1996

192 Kawa K: Diagnosis and treatment of Epstein-Barr virusassociated natural killer cell lymphoproliferative disease. Int $\mathrm{J}$ Hematol 78: 24-31, 2003

193 Tanner J, Weis J, Fearon D, Whang Y, Kieff E : Epstein-Barr virus gp350/220 binding to the B lymphocyte C3d receptor mediates adsorption, capping, and endocytosis. Cell 50: 203-213, 1987

194 Kaneko T, Fukuda J, Yoshihara T, Zheng H, Mori S, Mizoguchi $\mathrm{H}$, Oshimi K : Nasal natural killer (NK) cell lymphoma : report of a case with activated NK cells containing Epstein-Barr virus and expressing CD21 antigen, and comparative studies of their phenotype and cytotoxicity with normal NK cells. Br J Haematol 91: 355-361, 1995

195 Yoshiyama H, Imai S, Shimizu N, Takada K : Epstein-Barr virus infection of human gastric carcinoma cells : implication of the existence of a new virus receptor different from CD21. J Virol 71 : 5688-5691, 1997

196 Isobe Y, Sugimoto K, Yang L, Tamayose K, Egashira M, Kane- 


\section{R. Suzuki}

ko T, Takada K, Oshimi K : Epstein-Barr virus infection of human natural killer cell lines and peripheral blood natural killer cells. Cancer Res 64 : 2167-2174, 2004

197 Hammerschmidt W, Sugden B : Genetic analysis of immortalizing functions of Epstein-Barr virus in human B lymphocytes. Nature 340 : 393-397, 1989

198 Ohshima K, Suzumiya J, Kanda M, Kato A, Kikuchi M : Integrated and episomal forms of Epstein-Barr virus (EBV) in EBV associated disease. Cancer Lett 122: 43-50, 1998

199 Kagami Y, Nakamura S, Suzuki R, Iida S, Yatabe Y, Okada Y, Kobayashi T, Tsurumi T, Seto M, Ogura M, Taguchi O, Morishima Y : Establishment of an IL-2-dependent cell line derived from 'nasal-type' NK/T-cell lymphoma of $\mathrm{CD}^{+}, \mathrm{sCD}^{-}, \mathrm{CD} 3 \varepsilon^{+}$, $\mathrm{CD}^{+} 6^{+}$phenotype and associated with the Epstein-Barr virus. $\mathrm{Br}$ J Haematol 103 : 669-677, 1998

200 Nagata H, Numata T, Konno A, Mikata I, Kurasawa K, Hara S, Nishimura M, Yamamoto K, Shimizu N : Presence of natural killer-cell clones with variable proliferative capacity in chronic active Epstein-Barr virus infection. Pathol Int 51: 778-785, 2001

201 Suzuki K, Ohshima K, Karube K, Suzumiya J, Ohga S, Ishihara S, Tamura K, Kikuchi M : Clinicopathological states of EpsteinBarr virus-associated T/NK-cell lymphoproliferative disorders (severe chronic active EBV infection) of children and young adults. Int J Oncol 24 : 1165-1174, 2004

202 Mutirangura A, Pornthanakasem W, Theamboonlers A, Sriuranpong V, Lertsanguansinchi P, Yenrudi S, Voravud N, Supiyaphun P, Poovorawan Y : Epstein-Barr viral DNA in serum of patients with nasopharyngeal carcinoma. Clin Cancer Res 4: 665-669, 1998

203 Lei KIK, Chan LYS, Chan W-Y, Johnson PJ, Dennis Lo YM : Diagnostic and prognostic implications of circulating cell-free Epstein-Barr virus DNA in natural killer/T-cell lymphoma. Clin Cancer Res 8: 29-34, 2002

204 Chan KCA, Zhang J, Chan ATC, Lei KIK, Leung S-F, Chan LYS, Chow KCK, Lo YMD : Molecular characterization of circulating EBV DNA in the plasma of nasopharyngeal carcinoma and lymphoma patients. Cancer Res 63 : 2028-2032, 2003

205 Okano M, Matsumoto S, Osato T, Sakiyama Y, Thiele GM, Purtilo DT : Severe chronic active Epstein-Barr virus infection syndrome. Clin Microbiol Rev 4 : 129-135, 1991

206 Rowe DT, Qu L, Reyes J, Jabbour N, Yunis E, Putnam P, Todo $\mathrm{S}$, Green $\mathrm{M}$ : Use of quantitative competitive PCR to measure Epstein-Barr virus genome load in the peripheral blood of pediatric transplant patients with lymphoproliferative disorders. J Clin Microbiol 35 : 1612-1615, 1997

207 Stevens SJC, Pronk I, Middeldorp JM : Toward standardization of Epstein-Barr virus DNA load monitoring: unfractionated whole blood as preferred clinical specimen. J Clin Microbiol 39 : 1211-1216, 2001

208 Wadowsky RM, Laus S, Green M, Webber SA, Rowe D : Measurement of Epstein-Barr virus DNA loads in whole blood and plasma by TaqMan PCR and in peripheral blood lympho- cytes by competitive PCR. J Clin Microbiol 41 : 5245-5249, 2003

209 Drexler HG, Matsuo Y : Malignant hematopoietic cell lines : in vitro models for the study of natural killer cell leukemialymphoma. Leukemia 14 : 777-782, 2000

210 Matsuo Y, Drexler HG : Immunoprofiling of cell lines derived from natural killer-cell and natural killer-like T-cell leukemialymphoma. Leuk Res 27 : 935-945, 2003

211 Yodoi J, Teshigawara K, Nikaido T, Fukui K, Noma T, Honjo T, Takigawa M, Sasaki M, Minato N, Tsudo M, Uchiyama T, Maeda M : TCGF (IL 2)-receptor inducing factor (s). I. Regulation of IL 2 receptor on a natural killer-like cell line (YT cells). J Immunol 134 : 1623-1630, 1985

212 Gong JH, Maki G, Klingemann HG : Characterization of a human cell line (NK-92) with phenotypical and functional characteristics of activated natural killer cells. Leukemia $8: 652-658$, 1994

213 Kojima H, Suzukawa K, Yatabe Y, Hori M, Nagasawa T, Abe $\mathrm{T}$ : Establishment of a new natural killer (NK) cell line, TKS-1, from a patient with aggressive type of large granular lymphocyte (LGL) leukemia. Leukemia 8 : 1999-2004, 1994

214 Robertson MJ, Cochran KJ, Cameron C, Le JM, Tantravahi R, Ritz J : Characterization of a cell line, NKL, derived from an aggressive human natural killer cell leukemia. Exp Hematol 24 : 406-415, 1996

215 Tsuchiyama J, Yoshino T, Mori M, Kondoh E, Oka T, Akagi T, Hiraki A, Nakayama H, Shibuya A, Ma Y, Kawabata T, Okada S, Harada M : Characterization of a novel human natural killercell line (NK-YS) established from natural killer cell lymphoma/ leukemia associated with Epstein-Barr virus infection. Blood 92 : 1374- 1383, 1998

216 Tsuge I, Morishima T, Morita M, Kimura H, Kuzushima K, Matsuoka H: Characterization of Epstein-Barr virus (EBV)infected natural killer (NK) cell proliferation in patients with severe mosquito allergy; establishment of an IL-2-dependent NK-like cell line. Clin Exp Immunol 115 : 385-392, 1999

217 Yagita M, Huang CL, Umehara H, Matsuo Y, Tabata R, Miyake M, Konaka Y, Takatsuki K: A novel natural killer cell line (KHYG-1) from a patient with aggressive natural killer cell leukemia carrying a p53 point mutation. Leukemia 14 : 922-930, 2000

218 Nagata H, Konno A, Kimura N, Zhang Y, Kimura M, Demachi A, Sekine T, Yamamoto K, Shimizu N : Characterization of novel natural killer (NK)-cell and gammadelta T-cell lines established from primary lesions of nasal T/NK-cell lymphomas associated with the Epstein-Barr virus. Blood 97 : 708-713, 2001

219 Zhang Y, Nagata H, Ikeuchi T, Mukai H, Oyoshi MK, Demachi A, Morio T, Wakiguchi H, Kimura N, Shimizu N, Yamamoto K : Common cytological and cytogenetic features of Epstein-Barr virus (EBV)-positive natural killer (NK) cells and cell lines derived from patients with nasal $\mathrm{T} / \mathrm{NK}$-cell lymphomas, chronic active EBV infection and hydroa vacciniforme-like eruptions. $\mathrm{Br}$ 
J Haematol 121: 805- 814, 2003

220 Chen IM, Whalen M, Bankhurst A, Sever CE, Doshi R, Hardekopf D, Montgomery K, Willman CL: A new human natural killer leukemia cell line, IMC-1. A complex chromosomal rearrangement defined by spectral karyotyping: functional and cytogenetic characterization. Leuk Res 28 : 275-284, 2004

221 Hellmann D, Cowan MJ, Ammann AJ, Wara DW, Chudwin D, Chang RS: Chronic active Epstein-Barr virus infections in two immunodeficient patients. J Pediatr 103 : 585-588, 1983

222 Rickinson AB : Chronic, symptomatic Epstein-Barr virus infection. Immunol Today $7: 13-14,1986$

223 Kawa-Ha K, Franco E, Doi S, Yumura K, Ishihara S, Tawa A, Yabuuchi H: Successful treatment of chronic active EpsteinBarr virus infection with recombinant interleukin-2. Lancet 1 : 154, 1987

224 Quintanilla-Martinez L, Kumar S, Fend F, Reyes E, TeruyaFeldstein J, Kingma DW, Sorbara L, Raffeld M, Straus SE, Jaffe ES : Fulminant EBV (+) T-cell lymphoproliferative disorder following acute/chronic EBV infection : a distinct clinicopathologic syndrome. Blood 96: 443-451, 2000

225 Imashuku S, Kuriyama K, Teramura T, Ishii E, Kinugawa N, Kato M, Sako M, Hibi S: Requirement for etoposide in the treatment of Epstein-Barr virus-associaed hemophagocytic lymphohistiocytosis. J Clin Oncol 19 : 2665-2673, 2001

226 Kawa K, Okamura T, Yasui M, Sato E, Inoue M : Allogeneic hematopoietic stem cell transplantation for Epstein-Barr virusassociated T/NK-cell lymphoproliferative disease. Crit Rev Oncol Hematol 44 : 251-257, 2002

227 Ha SY, Chung CW, Ko YH : Severe chronic active EBV infection in an adult patient: case report. J Korean Med Sci 19 : 453-457, 2004

228 Tefferi A, Li C-Y, Witzig TE, Dhodapkar MV, Okuno SH, Phyliky RL: Chronic natural killer cell lymphocytosis : a descriptive clinical study. Blood 84 : 2721-2725, 1994

229 Rabbani GR, Phyliky RL, Tefferi A : A long-term study of patients with chronic natural killer cell lymphocytosis. Br J Haematol 106: 960-966, 1999

230 Ohno Y, Amakawa R, Fukuhara S, Huang CR, Kamesaki H, Amano H, Imanaka T, Takahashi Y, Arita Y, Uchiyama T, Kita $\mathrm{K}$, Miwa $\mathrm{H}$ : Acute transformation of chronic large granular lymphocyte leukemia associated with additional chromosome abnormality. Cancer 64: 63-67, 1989

231 Tagawa S, Mizuki M, Onoi U, Nakamura Y, Nozima J, Yoshida H, Kondo K, Mukai T, Yamanishi K, Kitani T: Transformation of large granular lymphocytic leukemia during the course of a reactivated human herpesvirus-6 infection. Leukemia 6 : 465-469, 1992

232 Matsubara A, Matsumoto M, Takada K, Hato T, Hasegawa H, Tamai T, Yasukawa M, Fujita S : Acute transformation of chronic large granular lymphocyte leukemia into an aggressive form associated with preferential organ involvement. Acta Haematol 91: 206-210, 1994

233 Loughran TP Jr, Zambello R, Ashley R, Guderian J, Pellenz M,
Semenzato G, Starkebaum G : Failure to detect Epstein-Barr virus DNA in peripheral blood mononuclear cells of most patients with large granular lymphocyte leukemia. Blood 81 : 2723-2727, 1993

234 Loughran TP Jr, Hadlock KG, Yang Q, Perzova R, Zambello R, Semenzato G, Foung SK, Poiesz BJ : Seroreactivity to an envelope protein of human T-cell leukemia/lymphoma virus in patients with CD3- (natural killer) lymphoproliferative disease of granular lymphocytes. Blood 90 : 1977- 1981, 1997

235 Perzova RN, Loughran TP, Dube S, Ferrer J, Esteban E, Poiesz BJ : Lack of BLV and PTLV DNA sequences in the majority of patients with large granular lymphocyte leukaemia. Br J Haematol 109: 64-70, 2000

236 Miller TP, Dahlberg S, Cassady JR, Adelstein DJ, Spier CM, Grogan TM, LeBlanc M, Carlin S, Chase E, Fisher RI : Chemotherapy alone compared with chemotherapy plus radiotherapy for localized intermediate- and high-grade non-Hodgkin's lymphoma. N Engl J Med 339 : 21-26, 1998

237 Horning SJ, Weller E, Kim K, Earle JD, O'Connell MJ, Habermann TM, Glick JH : Chemotherapy with or without radiotherapy in limited-stage diffuse aggressive non-Hodgkin's lymphoma : Eastern Cooperative Oncology Group study 1484. J Clin Oncol 22 : 3032-3038, 2004

238 Ohtsu A, Boku N, Muro K, Chin K, Muto M, Yoshida S, Satake M, Ishikura S, Ogino T, Miyata Y, Seki S, Kaneko K, Nakamura A : Definitive chemoradiotherapy for T4 and/or M1 lymph node squamous cell carcinoma of the esophagus. J Clin Oncol 17 : 2915-2921, 1999

239 Pignon JP, Bourhis J, Domenge C, Designe L : Chemotherapy added to locoregional treatment for head and neck squamouscell carcinoma: Three meta-analyses of updated individual data ? MACH-NC Collaborative Group. Meta-Analysis of Chemotherapy on Head and Neck Cancer. Lancet 355 : 949-955, 2000

240 Furuse K, Fukuoka M, Kawahara M, Nishikawa H, Takada Y, Kudoh S, Katagami N, Ariyoshi Y : Phase III study of concurrent versus sequential thoracic radiotherapy in combination with mitomycin, vindesine, and cisplatin in unresectable stage III nonsmall-cell lung cancer. J Clin Oncol 17 : 2692-2699, 1999

241 Teshima T, Miyaji R, Fukuda M, Ohshima K : Bone-marrow transplantation for Epstein-Barr-virus-associated natural killer cell-large granular lymphocyte leukaemia. Lancet 347: 1124, 1996

242 Liang R, Chen F, Lee CK, Kwong YL, Chim CS, Yau CC, Chiu $\mathrm{E}$ : Autologous bone marrow transplantation for primary nasal T/NK cell lymphoma. Bone Marrow Transplant 19: 91-93, 1997

243 Takami A, Nakao S, Yachie A, Kasahara Y, Okumura H, Miura Y, Sugimori N, Zeng W, Wang H, Kotani T, Shiobara S, Matsuda T: Successful treatment of Epstein-Barr virus-associated natural killer cell large granular lymphocytic leukaemia using allogeneic peripheral blood stem cell transplantation. Bone Marrow Transplant 21: 1279-1282, 1998 


\section{R. Suzuki}

244 Nawa Y, Takenaka K, Shinagawa K, Deguchi S, Matsumura N, Koyama S, Hiramatsu Y, Omoto E, Yoshino T, Harada M : Successful treatment of advanced natural killer cell lymphoma with high-dose chemotherapy and syngeneic peripheral blood stem cell transplantation. Bone Marrow Transplant 23 : 1321-1322, 1999

245 Sasaki M, Matsue K, Takeuchi M, Mitome M, Hirose Y : Successful treatment of disseminated nasal NK/T-cell lymphoma using double autologous peripheral blood stem cell transplantation. Int J Hematol 71: 75- 78, 2000

246 Nagafuji K, Fujisaki T, Arima F, Ohshima K : L-asparaginase induced durable remission of relapsed nasal NK/T-cell lymphoma after autologous peripheral blood stem cell transplantation. Int J Hematol 74 : 447-450, 2001

247 Takenaka K, Shinagawa K, Maeda Y, Makita M, Kozuka T, Ashiba A, Yamamoto K, Fujii N, Nawa Y, Hiramatsu Y, Sunami K, Ishimaru F, Yoshimo T, Kiura K, Harada M : High-dose chemotherapy with hematopoietic stem cell transplantation is effective for nasal and nasal-type CD56+ natural killer cell lymphomas. Leuk Lymphoma 42: 1297-1303, 2001

248 Sanda T, Iida S, Ito M, Tsuboi K, Miura K, Harada S, Komatsu H, Wakita A, Inagaki H, Ueda R : Successful treatment of nasal T-cell lymphoma with a combination of local irradiation and high-dose chemotherapy. Int J Hematol 75 : 195-200, 2002

249 Makita M, Maeda Y, Takenaka K, Shinagawa K, Sunami K, Hiramatsu Y, Fujii N, Ishimaru F, Ikeda K, Niiya K, Yoshino T, Harada M : Successful treatment of progressive NK cell lymphoma with allogeneic peripheral stem cell transplantation followed by early cyclosporine tapering and donor leukocyte infusions. Int J Hematol 76: 94- 97, 2002

$250 \mathrm{Au}$ WY, Lie AK, Liang R, Kwong YL, Yau CC, Cheung MM, Ngan KC, Lau WH, Wong KH, Yiu HY, Cheng HC, Au KH, Chan JK: Autologous stem cell transplantation for nasal NK/Tcell lymphoma : a progress report on its value. Ann Oncol 14 : 1673-1676, 2003
251 Izutsu K, Kanda Y, Ohno H, Sao H, Ogawa H, Miyazaki Y, Kawa K, Kodera Y, Kato S, Morishima Y, Hirai H : Unrelated bone marrow transplantation for non-Hodgkin lymphoma: a study from the Japan Marrow Donor Program. Blood 103 : 1955-1960, 2004

252 Murashige N, Kami M, Kishi Y, Kim S-W, Takeuchi M, Matsue K, Kanda Y, Hirokawa M, Kawabata Y, Matsumura T, Kusumi E, Hirabayashi N, Nagafuji K, Suzuki R, Takeuchi K, Oshimi K : Allogeneic haematopoietic stem cell transplantation as a promising treatment for natural killer-cell neoplasms. Br J Haematol 130 : 561-567, 2005

253 Aviles A, Neri N, Fernandez R, Calva A, Huerta-Guzman J, Nambo MJ : Nasal NK/T-cell lymphoma with disseminated disease treated with aggressive combined therapy. Med Oncol 20 : 13-17, 2003

254 Yong W, Zheng W, Zhang Y, Zhu J, Wei Y, Zhu D, Li J : Lasparaginase-based regimen in the treatment of refractory midline nasal/nasal-type T/NK-cell lymphoma. Int J Hematol 78 : $163-167,2003$

255 Obama K, Tara M, Niina K : L-asparaginase-based induction therapy for advanced extranodal NK/T-cell lymphoma. Int $J$ Hematol 78 : 248-250, 2003

256 Matsumoto Y, Nomura K, Kanda-Akano Y, Fujita Y, Nakao M, Ueda K, Horiike S, Yokota S, Kusuzaki K, Kitoh T, Watanabe A, Taniwaki M : Successful treatment with Erwinia L-asparaginase for recurrent natural killer/T cell lymphoma. Leuk Lymphoma 44: 879-882, 2003

257 Yazawa Y, Takagi T, Asakura S, Suzuki K, Kano Y : Effects of 4-hydroperoxy ifosfamide in combination with other anticancer agents on human cancer cell lines. J Orthop Sci 4 : 231-237, 1999

258 Akutsu M, Furukawa Y, Tsunoda S, Izumi T, Ohmine K, Kano $\mathrm{Y}$ : Schedule-dependent synergism and antagonism between methotrexate and cytarabine against human leukemia cell lines in vitro. Leukemia 16 : 1808-1817, 2002 